Copyright (C) The author(s), 2016.

ISSN 2421-7131

a/ working paper

[online]

The Italian Association for the Study of Economic Asymmetries (a/simmetrie) was established in 2013 as an independent, nonprofit think-tank based in Rome (Italy). a/simmetrie undertakes applied research and policy analysis on economic asymmetries, both in their economic nature, and in their political and juridical implications; provides a forum for the advocacy of policies leading to a more equitable and sustainable growth; and promotes the public debate in the field of economic policy-making, by involving researchers, politicians, and other relevant stakeholders.

The a/simmetrie working paper series publishes outputs from a/simmetrie research in progress, as well as papers presented at $\mathrm{a} /$ simmetrie conferences and seminars, and contributions from visiting fellows. Comments are welcome. Unless otherwise indicated, the views expressed in this publication are those of the author(s). Publication does not imply endorsement by a/simmetrie.

Italian Association for the Study of Economic Asymmetries via Filippo Marchetti 19, I-00199 Roma, Italy www.asimmetrie.org info@asimmetrie.org 


\title{
Italy's Decline and the Balance-of-Payments Constraint: a Multicountry Analysis ${ }^{\S}$
}

\author{
Alberto BAGNAI \\ Department of Economics, Università 'Gabriele D'Annunzio' \\ viale Pindaro 42, I-65127, Pescara (Italy) \\ email: bagnai@unich.it \\ INFER - International Network for Economic Research \\ Bismarckstr. 19, 53113 Bonn (Germany).
}

\begin{abstract}
According to the literature, the decline experienced by the Italian economy in the last two decades depends on a slowdown of its labor productivity, starting in the Nineties. The supply-side explanations of this slowdown are inconsistent with the major stylized facts. In this paper, we verify whether a better explanation is provided by the effect of a negative demand shock, through Italy's external constraints, in the framework of Kaldor-DixonThirlwall cumulative growth model. To this end, we use a multi-country generalization of Thirlwall's balance-of-payments-constrained growth model, which allows us to investigate the contribution of Italy's main trade partners to Italy's long-run growth from 1970 to 2010. The trade partners are disaggregated into seven groups: Eurozone core, Eurozone periphery, United States, other European countries, OPEC countries, BRIC, and the rest of the world. The results show that Italy's long-run growth has been consistent with the Bop-constraint, that its decline can be explained by a progressive tightening of this constraint, that the sudden slowdown of labor productivity in the Nineties corresponds with a major shock on Italy's external constraint, and that the major contributions to this shock came, through different channels of transmission, from the core Eurozone countries and from OPEC countries.
\end{abstract}

JEL: E120, F430, O240

Keyword: General aggregative model: post-Keynesian. Economic growth of op economies. Development planning and policy: trade policy, foreign exchange policy.

\footnotetext{
$\S$ Paper presented at the $15^{\text {th }}$ INFER Annual Conference (University of Orléans, May $29^{\text {th }}$ June $1^{\text {st }}$, 2013). The author thanks Elias Soukiazis and two anonymous referees for their helpful comments, as well as Christian Alexander Mongeau Ospina for his research assistance, and Patrick Lynch for revising my English. All remaining errors are my own. Financial support from the Nando Peretti Foundation (Grant 2014-07) is gratefully acknowledged.
} 


\section{Introduction}

Italy's real growth rate was on average equal to $3.8 \%$ in the Seventies, $2.4 \%$ in the Eighties, $1.6 \%$ in the Nineties, and $0.4 \%$ in the last decade (AMECO, 2012). The other members of the 12 countries Eurozone ${ }^{1}$ (henceforth, EZ) followed a similar pattern (Figure 1): their average growth rate was $3.4 \%$ in the Seventies, $2.4 \%$ in the Eighties, $2.3 \%$ in the Nineties and $1.3 \%$ in the last decade. However, while in the Seventies and Eighties Italy's growth rate was slightly above, or equal to, the EZ average, in the last two decades it fell below it by almost one percentage point. This growth slowdown is reflected by Italy's GDP per capita measured at purchasing power parity (PPP). From the beginning of the Eighties until 1997 Italy ranked consistently $7^{\text {th }}$ in the EZ. Starting in 1997, Italy lost ground, and since 2001 it ranks $9^{\text {th }}$, followed by Greece, Portugal and Spain, and it is expected by the last World Economic Outlook (IMF, 2014) to lose fourther ground starting in 2018, when it will be overcome by Spain.

In the last decade several studies addressed Italy's decline (Daveri and Jona-Lasinio, 2005; Parisi et al., 2006; Carlucci, 2008; Rabellotti et al., 2009; Daveri and Parisi, 2010; Ramazzotti, 2010), reaching a consensus on the fact that Italy's decline depends on a fall in labour productivity growth. These studies adopts mostly the standard neoclassical exogenous growth framework, but generally fail to provide a convincing explanation of a major stylized fact: the sudden stop of labour productivity growth experienced in Italy around 1995, after three decades of relatively good performance (Figure 2). The purpose of this paper is to examine whether this fact can be explained by studying Italy's decline from an alternative perspective, that of the cumulative growth model developed by Kaldor (1970) and formalized by Dixon and Thirlwall (1975) and Thirlwall (2002). The KaldorDixon-Thirlwall (KDT) model describes how a demand shock can have cumulative, selfsustained, effects on long-run productivity growth, because of the interaction between Thirlwall's (1979) balance-of-payments constraint, and Verdoorn's (1949) dynamic increasing return model (see also McCombie et al., 2002). In this paper we hypothesize that the decline of Italy's real growth may depend on a vicious circle of this kind. Since Ofria and Millemaci (2010) show that Verdoorn's law is structurally stable in the Italian

\footnotetext{
${ }^{1}$ On January 1, 1999, the euro was adopted as an official currency by the 11 countries that had met the so called Maastricht criteria: Austria, Belgium, Finland, France, Germany, Ireland, Italy, Luxembourg, Netherlands, Portugal, Spain. In 2000 Greece qualified and was admitted to join the Eurozone on January 1,2001 , when the euro replaced the national currencies in circulation.
} 
economy, we verify whether Italy was set on a lower productivity growth path by a shock affecting the other building block of the KDT model, namely, the BoP constraint.

To this end, we investigate the presence of structural breaks in a multicountry version of Thirlwall's (1979) law, considering the bilateral trade flows between Italy and its trade partners. This allows us to measure the contributions of each partner area to the evolution of the Bop constraint, focussing on four distinct channels of transmission: a volume effect (for instance, sustained growth in a partner area lifts up the balance-of-payments constraint by promoting exports in the reporting country); a relative price effect (if the Marshall-Lerner conditions are met, protracted real devaluation in a partner area tightens the balance-of-payments constraint in the reporting country, by reducing its net exports), a market share effect (for instance, a reorientation of exports towards fast growing areas could lift up the constraint) and a structural break effect, determined by structural breaks in the underlying trade equations' parameters (e.g., a decrease in the elasticity of exports towards a partner area income would make the constraint more binding). This generalisation enables us to address four key research questions, namely: did European monetary integration, and in particular EZ membership, foster or hinder Italy's economic growth? Was Italy's growth harmed by the competition from the emerging market economies? What was the impact on Italy's long-run growth of the so-called 'energy bill' (namely, the need to pay for imported sources of energy, like oil and natural gas)? Is Italy plagued by a general competitiveness problem towards all its partners, or do the bilateral trade patterns reveal a more complex picture?

In order to investigate these issues, the empirical analysis considers seven partner areas: the EZ core (Austria, Belgium, Finland, France, Germany, and the Netherlands), the EZ periphery (Greece, Ireland, Portugal, Spain), the United States, the non-EZ OECD European countries (Denmark, Sweden, Switzerland, United Kingdom), the OPEC countries, the BRIC countries, and the rest of the world, using annual bilateral trade data from 1970 to 2010. The presence of structural breaks in Italy's BoP constraint is assessed by estimating the long-run trade relations between Italy and its partners through appropriate cointegration estimators, which take into account the existence of up to two structural break of unknown date in the parameters (Gregory and Hansen, 1996; HatemiJ, 2008). 
The remainder of the paper is structured in five sections. Section 2 sets out the main stylized facts and reviews the relevant literature. Section 3 describes the generalised version of Thirlwall's law adopted in the empirical analysis. Section 4 illustrates the data set and the estimation methodology. Section 5 presents the empirical results. Section 6 draws some conclusions and suggestions for further research.

\section{A Review of the Stylized Facts and of the Literature}

The top panel of Table 1 shows the average real growth rate in Italy and in the EZ, as well as in the EZ core and periphery. ${ }^{2}$ In 1960 the peripheral countries (Ireland, Spain, Greece and Portugal) occupied the last four positions (from the $9^{\text {th }}$ to the $12^{\text {th }}$ ) in the real GDP per capita ranking of the EZ, while Italy ranked $8^{\text {th }}$. The periphery's growth rate has since then been higher than that of the core. Italy followed a different path. Its growth rate was initially higher than that of the core, then fell behind starting in the Nineties. In the last decade, real GDP growth in Italy averaged 0.4, about one point below the EZ average, and 1.6 points below the periphery average. The same pattern emerges, with minor modifications, looking at real GDP per capita (Table 1).

Daveri and Jona-Lasinio (2005) stated that the relative decline of Italy's per capita GDP was worrying because it could herald an absolute decline. Unfortunately, they were right (Figure 3). The performance of the Italian economy in the last economic crisis was especially bad: Italy experienced the second largest cumulative fall in real GDP growth after Greece, with -8.7 points from 2008 to 2013 . The situation was not rosy before the crisis either, with an average growth of $0.7 \%$ from 2000 to 2008.

The relative decline of the Italian economy coincides with a decline in its labour productivity growth, which starts in the Eighties and becomes dramatic in the last decade, when the growth of labour productivity zeroes, and the productivity growth gap between Italy and the two other largest EZ economies reaches 1 point (Table 2).

Daveri and Jona-Lasinio (2005) analyse this pattern in detail, finding that: the decline of Italian GDP growth depends on a decline in labour productivity, not in hour worked,

\footnotetext{
${ }^{2}$ Following Busetti et al. (2006), we identify as the EZ 'core' the countries that belong to the same 'inflation convergence club' as Germany (i.e., Austria, Belgium, Finland, France, Luxembourg, and the Netherlands), and as 'periphery' the high inflation countries (Greece, Ireland, Portugal and Spain), whereas Italy constitutes a 'medium inflation club' in its own.
} 
contrary to the conclusions reached by Alesina et al. (2005), according to which 'Europeans today work much less than Americans'; this decline has affected in particular the manufacturing sector (especially the durables sector); the decline is mostly due to a 'within' effect, i.e. to decreasing productivity growth in each industry, rather than a 'between' effect, i.e. to flagging reallocation of workers from low to high productivity sectors; finally, this process took place with almost unchanged capital deepening, and it is therefore due to a fall in total factor productivity, which was particularly striking in all the Made-in-Italy consumer industries.

Figure 2 displays the labour productivity patterns (GDP per hour worked in the whole economy) in the three largest EZ economies, taking 1970 as the basis year. A major stylized fact is apparent: until the beginning of the Nineties, Italian productivity kept apace with that of the two other major EZ economies; then, Italy fell behind in two steps: from 1990 to 1993, and from 1996 onwards. Since then, labour productivity stagnated. In fact, 1996 is found to be the turning point of Italian productivity growth by most studies. Any explanation of Italy's decline should be evaluated against this fact.

Some authors have traced back the low productivity of Italian manufacturing firms to their 'dwarfism', i.e. to their organization in industrial districts (IDs) of small and medium enterprises. This model of development would not allow the Italian firms to benefit of economies of scale, and it would prevent them to engage in a significant R\&D activity, which is shown to be a crucial boost to total factor productivity (Parisi et al., 2006). However, Rabellotti et al. (2009) argue that until the beginning of the Nineties the Italian IDs had shown a remarkable economic dynamism, thanks to their pattern of industrial development based on 'flexible specialization' (Pyke and Sengerberger, 1992). Moreover, Belussi and Pilotti (2002) argue that despite their relatively low level of formal R\&D expenditure, the IDs, thanks to technological externalities, favour product and process innovation through informal research, that leads to economically relevant innovations. It is also worth noting that the data on aggregate research expenditure do not show a sudden fall in correspondence with the decline of Italian productivity. Formal $\mathrm{R} \& \mathrm{D}$ expenditure is relatively stable, or moderately rising, at around 1\% of GDP (OECD, 2013). While this is about a half of the levels prevailing in France and Germany, this difference is stable, and could be accounted for by the respective models of industrial organisation. Besides that, since Italian firms did not shrink all at once in 1995 , 
'dwarfism' per se does not explain the sudden fall in Italian productivity growth rate occurring in the mid-Nineties. The 'dwarfism' argument therefore seems relatively unconvincing, especially because it fails to explain the timing of Italian labour productivity slowdown.

Daveri and Parisi (2010) provide a different explanation. Using microlevel data on a panel of Italian firm, they investigate the fall in labour productivity occurred between 2001 and 2003 (see Figure 2), and find support for the 'labour supply view' (Gordon and DewBecker, 2008), according to which labour market reforms had a negative impact on labour productivity. In fact, the 'upward wage rigidity' introduced by the reforms (Pastore, 2010) may have encouraged the entrepreneurs to adopt relatively more labour-intensive techniques. Therefire, the supposedly positive effects of flexibility in reducing unemployment may have occurred at the expenses of labour productivity. Daveri and Parisi (2010) actually find that productivity appears to be lower in firms with a higher share of part-time or temporary workers. This suggests that the mid-Nineties productivity stop depends on the labour market reforms carried out by Prodi government (the so called 'Treu package'; Sciulli, 2006; Barbieri and Scherer, 2009). Yet, the 'flexibilization' package was approved on June 1997, but the decline had started at the end of 1995. Moreover, there had been another episode of 'sudden stop' in productivity growth in 1989, when no particular 'flexibilization' of the labour market was being implemented. Therefore, while giving interesting insights on the persistence of Italy's decline, this explanation is not completely consistent with its timing.

\section{A Generalised Cumulative Growth Model and Italy's Decline}

The KDT growth model provides an alternative and possibly more consistent explanation. Following Thirlwall (2002, chap. 4), the model consists of two equations:

$$
\left\{\begin{array}{l}
\dot{Y}_{B P}=\frac{(1-\eta-\psi)\left(\dot{W}-\dot{A}+\dot{T}-\dot{E}-\dot{P}_{f}\right)+\varepsilon \dot{Z}}{\pi} \\
\dot{A}=\varphi_{0}+\varphi_{1} \dot{Y}_{B P}
\end{array}\right.
$$

where $\dot{Y}_{B P}$ is the BoP-constrained growth rate, $W$ nominal wages, $A$ average labour productivity, $T$ is one plus a percentage mark-up, $E$ the nominal exchange rate (local 
currency units for a unit of foreign currency), $P_{f}$ foreign prices, $Z$ world demand (a dot over a variable indicates its growth rate), $\eta$ is the elasticity of exports to relative prices, $\psi$ the elasticity of imports to relative prices, $\varepsilon$ the elasticity of exports to world demand, $\pi$ the elasticity of imports to domestic demand, $\varphi_{0}$ is the rate of autonomous productivity growth and $\varphi_{1}$ is Verdoorn's coefficient. The first equation (Thirlwall's law) defines the BoP-constrained growth rate, i.e. the real rate of growth compatible with current account equilibrium; the second equation is Verdoorn's law, defining the long-run rate of productivity growth.

Two features of this model are worth noting. Firstly, its circular nature: according to Verdoorn's law, a faster growth of output brings about a faster growth of productivity, which, in turn, implies a slower growth of unit labour costs, and hence a faster growth of exports and output (provided the Marshall-Lerner condition is met). Secondly, its cumulative nature: as Thirlwall (2002) puts it, “once a country obtains a growth advantage, it will tend to sustain it". An equal and opposite reaction occurs if a country undergoes a negative growth shock: in this case, the country can be trapped in a lowproductivity growth path. As for the possible shocks, centre-periphery growth models have typically focused on changes in the income elasticities of exports and imports, $\varepsilon$ and $\pi$, respectively. However, in principle a self-sustained growth advantage or disadvantage could be triggered also by the first term at the numerator of Thirlwall's law, i.e., by a shock to the rate of change of the real exchange rate (due for instance to a change in the currency regime, or in the reporting or partner countries' income policies).

These properties bear some relation to our analysis. As mentioned in Section 2, a striking feature of labour productivity in Italy is that it flattened around 1996, the year in which the Italian lira revaluated and re-joined the Exchange Rate Mechanism of the European Monetary System (EMS). Figure 4 shows that since then the nominal effective exchange rate of Italy has constantly appreciated, going from a sustained devaluation equal to about $5 \%$ per year from 1970 to 1995 , to a steady revaluation at about $1 \%$ per year afterwards (Table 3). Model (1) suggests that this major and persistent shock to $\dot{E}$ (a decrease by about 6 percentage points) may have affected average productivity growth. Therefore, the KDT model has the merit to reconcile the timing of a major stylized fact (the slowdown of Italian labour productivity) with a major structural change in Italian economic policy 
(the decision of Italy to re-join the EMS). Yet, a number of cautionary remarks are needed, concerning both the model structure, and its suitability to the data.

First of all, a shock to the nominal exchange rate affects productivity growth only to the extent that it determines a persistent change in the rate of change of the real exchange rate. ${ }^{3}$ Whether this occurs depends crucially on the behaviour of nominal wages: typically, real wage resistance may prevent a continuous change in the real exchange rate to occur (Wilson, 1976). In this respect, it is worth noting that the KDT model treats nominal wages growth as exogenous, and as such it cannot shed any light on whether and to what extent real wage resistance will occur. ${ }^{4}$ As a matter of fact, Table 3 shows that before 1996 the sustained nominal depreciation did not translate significantly into real depreciation; however, from 1996 onward the Italian real effective exchange rate experienced a sustained appreciation at a rate of about 3.5\% per year. Therefore, the occurrence of a persistent change in the rate of real depreciation, such as to trigger a change in productivity growth, has proven empirically relevant. The questions then arises as to what determined this outcome: some authors point out the impact of emerging markets on Italian competitiveness (Montalbano and Nenci, 2011), with a particular emphasis on China, where a steady fall in unit labour costs contributed to worsen the trade partners' real exchange rates (Lewley at al. 2012); other authors stress the role of Germany's ordoliberal income policies in altering the pattern of intra-EZ price competitiveness (Cesaratto and Stirati, 2010; Trautwein and Körner, 2014).

Whether and to what extent these or other country specific factors have affected Italy's balance-of-payments constraint is an empirical matters, since their actual impact depends on the countries' respective trade shares. For instance, nominal revaluation around the mid-Eighties was not followed by a stop in productivity growth (Figure 4), apparently disproving the model. However, from 1986 to 1988 the revaluation was driven by the

${ }^{3}$ Since the balance-of-payments constraint is derived under the hypothesis of current account equilibrium, a real exchange rate depreciation relieves the constraint to the extent that the Marshall-Lerner condition is met. It is worth noting, however, that whenever the current account starts from a deficit position, more restrictive conditions are needed. Gandolfo (2002, p. 7.2) provides a full discussion.

${ }^{4}$ I thank an anonymous referee for this remark. While limiting its usefulness for the purposes of economic policy analysis, this shortcoming leaves unaffected the capability of the model to explain the historical developments of the balance-of-payments constrained growth rate, conditional on an historically given path of nominal wages. The purpose of the original paper by Dixon and Thirlwall (1975) was to explain regional growth differentials. This justified the assumption of nominal wage exogeneity, since it can be argued that collective agreements at the national level make the evolution of nominal wages largely exogenous to region-specific features. 
large devaluation of the US dollar after the Plaza agreement (September 1985). Since the market share of the US in Italian trade is relatively low (about 7\%), the impact on growth and productivity was relatively minor. A productivity slowdown is visible after 1988, when the lira revaluated against the ECU and entered the 'narrow band' within the EMS (on January 5, 1990). This policy change determined a revaluation with respect to the core-EZ (accounting for $42 \%$ of Italian trade).

The above discussion points out the need to extend the model in order to take into account the behaviour of the bilateral trade flows between Italy and its major partner areas. For this purpose, we reformulated the balance-of-payments constraint, assuming that the reporting country $i$ has $n$ partner countries $j=1, \ldots, n$. The multilateral balance-ofpayments constraint becomes

$$
P \sum_{j=1}^{n} X_{j}=\sum_{j=1}^{n} E_{j} P_{j} M_{j}
$$

where $P$ are the reporting country export prices, $X_{j}$ are exports to partner country $j, E_{j}$ is the bilateral nominal exchange rate (units of reporting country's currency for one unit of partner's $j$ currency), $P_{j}$ are country $j$ export prices, and $M_{j}$ are imports from partner $j$. Taking growth rates in Equation (2) and substituting in it standard trade equations we obtain the generalised BoP-constrained growth rate:

$$
\dot{Y}_{B P}=\frac{\sum_{j=1}^{n} \dot{R}_{j}\left[\mu_{j}\left(1-\psi_{j}\right)-v_{j} \eta_{j}\right]+\sum_{j=1}^{n} v_{j} \varepsilon_{j} \dot{Y}_{j}}{\sum_{j=1}^{n} \mu_{j} \pi_{j}}
$$

where $\dot{R}_{j}$ is the rate of change of the bilateral real exchange rate (relative prices) between country $i$ and country $j$ (positive values indicate a real appreciation of domestic currency), $\dot{Y}_{j}$ is the real rate of growth of country $j, \mu_{j}$ is the market share of country $j$ on total imports, $v_{j}$ is the market share of country $j$ on total exports, ${ }^{5} \psi_{j}$ and $\eta_{j}$ are the elasticities

${ }^{5}$ More precisely, $\mu_{j}=\left(E_{j} P_{j} M_{j}\right) / \sum_{j} E_{j} P_{j} M_{j}$ and $v_{j}=X_{j} / \sum_{j} X_{j}$, where $P$ are the reporting country export prices, $X_{j}$ are exports to partner country $j, E_{j}$ is the bilateral nominal exchange rate (units of reporting country's currency for one unit of partner's $j$ currency), $P_{j}$ are country $j$ export prices, and $M_{j}$ are imports from partner $j$. 
to relative prices of imports from country $j$ and exports to country $j$, respectively, and $\pi_{j}$ and $\varepsilon_{j}$ are the elasticities to income of imports from country $j$ and exports to country $j$, respectively. ${ }^{6}$

Owing to its structure, the generalised law (3) cannot be additively decomposed as the sum of $n$ 'partner-j-bilateral-BoP-constrained rates', depending each on partner $j$ variables only. This outcome reflects an economic fact: bilateral deficits per se do not constrain an economy. Country $i$ can keep buying forever good $a$ from country $j$, provided it keeps selling enough good $b$ to country $k$ to finance its purchases. Since in a multilateral setting there is no obligation to finance imports from country $j$ only with the proceedings of exports to country $j$, the Bop constraint does not reduce to an additive function of bilateral balances. This does not mean that bilateral imbalances are uninformative or irrelevant. Rather, it implies that in order to orient the policy action one must look at the impact of partner's $j$ variables on the overall Bop constraint, i.e. at the partial derivatives of $\dot{Y}_{B P}$ with respect to partner $j$ variables and parameters.

By evaluating these derivatives, we find that: $\partial \dot{Y}_{B P} / \partial \dot{Y}_{j}=\pi^{-1} v_{j} \varepsilon_{j}\left(\right.$ where $\left.\pi=\sum_{j} \pi_{j}\right)$, i.e., an increase in the $j^{\text {th }}$ partner country growth rate, $\dot{Y}_{j}$, has a positive effect on $\dot{Y}_{B P}$; $\partial \dot{Y}_{B P} / \partial \dot{R}_{j}=\pi^{-1}\left[\mu_{j}\left(1-\psi_{j}\right)-v_{j} \eta_{j}\right]$, i.e., an increase in the growth rate of bilateral relative prices, $\dot{R}_{j}$, has a negative effect on $\dot{Y}_{B P}$, provided the market-shares-weighted MarshallLerner condition for the bilateral relation with partner $j$ is respected, i.e. provided $\mu_{j}-\mu_{j} \psi_{j}-v_{j} \eta_{j}<0 ; \partial \dot{Y}_{B P} / \partial v_{j}=\pi^{-1} \dot{X}_{j}$, i.e., an increase in a bilateral exports market share, $v_{j}$, has a positive effect on $\dot{Y}_{B P}$, provided the corresponding real bilateral exports are growing; $\partial \dot{Y}_{B P} / \partial \mu_{j}=\pi^{-1}\left[\dot{R}_{j}\left(1-\psi_{j}\right)-\pi_{j} \dot{Y}_{B P}\right]:$ the effect on $\dot{Y}_{B P}$ of an increase in a bilateral import market share $\mu_{j}$ is ambiguous in principle, but it turns out to be negative for plausible values of the relevant elasticities, ${ }^{7}$ and in any event is more likely to be negative the larger the income and price elasticities of the corresponding bilateral import demand function; $\partial \dot{Y}_{B P} / \partial \varepsilon_{j}=\pi^{-1}\left(v_{j} \dot{Y}_{j}\right)$, i.e., an increase in a bilateral income elasticity

\footnotetext{
${ }^{6}$ In the limit case in which $n=1$, the import and export trade shares are equal to 1 and Equation (3) reduces to the aggregate formulation of Thirlwall's law (the first equation of model (1) above).

${ }^{7}$ Consider that in the import functions, income elasticities are usually larger than price elasticities.
} 
of exports, $\varepsilon_{j}$, has a positive effect on $\dot{Y}_{B P}$, provided country $j$ is growing; $\partial \dot{Y}_{B P} / \partial \eta_{j}=\pi^{-1}\left(-v_{j} \dot{R}_{j}\right)$, i.e., an increase in a bilateral price elasticity of exports, $\eta_{j}$, has a negative effect on $\dot{Y}_{B P}$ if the corresponding real bilateral exchange rate is appreciating; $\partial \dot{Y}_{B P} / \partial \pi_{j}=\pi^{-1}\left(-\mu_{j} \dot{Y}_{B P}\right)$, i.e., an increase in a bilateral income elasticity of imports, $\pi_{j}$, has a negative effect on $\dot{Y}_{B P}$, provided $\dot{Y}_{B P}$ is positive; finally, $\partial \dot{Y}_{B P} / \partial \psi_{j}=\pi^{-1}\left(-\mu_{j} \dot{R}_{j}\right)$, i.e., an increase in a bilateral price elasticity of imports, $\psi_{j}$, has a negative effect on $\dot{Y}_{B P}$ if the corresponding real bilateral exchange rate is appreciating.

The intuition behind these effects is straightforward. In particular, the bilateral MarshallLerner condition requires that the sum of bilateral price elasticities, each weighed with its own market share, must exceed the imports market share. ${ }^{8}$ Following Thirlwall and Hussain (1982, equation 16), $\mu_{j}$ is the bilateral 'pure terms of trade' effect, while $\mu_{j} \psi_{j}+v_{j} \eta_{j}$ represents the 'volume effect' of a relative price change. For a real bilateral devaluation to be successful, the second effect must outweigh the first.

\section{Model Estimation}

\subsection{Data Sources and Properties}

As mentioned in the Introduction, we considered the following aggregation of Italy's trade partners: EZ core countries (Austria, Belgium, Finland, France, Germany, Luxembourg, Netherlands); EZ periphery countries (Greece, Ireland, Portugal, Spain); United States; other OECD European countries (Denmark, Sweden, Switzerland, United Kingdom); OPEC countries; BRIC countries; Rest of the world. The split of the EZ in three 'clubs' follows Busetti et al. (2006) and has been discussed in Section 2 above. The United States is considered in its own, because it accounts for a sizeable market share of Italy's trade (although its market share on Italy's trade has been slightly decreasing, ranging from about $8 \%$ in the Seventies to $6 \%$ in the last decade). We did not consider all the non-EZ OECD European countries, but only the first four in order of importance. The remaining countries are negligible in terms of market shares and were included in the rest condition.

${ }^{8}$ By summing-up these conditions over the $n$ partners we get the aggregate Marshall-Lerner 
of the world. Our disaggregation highlights the role of the OPEC and BRIC countries, in order to investigate to what extent energy imports have dragged down Italy's long-run growth, and the competition from the emerging economies has had depressing effects.

The long-run elasticities featuring in Equation (3) were estimated on annual data from 1970 to 2010. Our main source for bilateral trade data was the International Trade by Commodity Statistics (ITCS) database (OECD, 2013), that reports the bilateral trade flows of each OECD member towards all its trade partners, expressed in current USD. ${ }^{9}$ Bilateral exports data were expressed in real terms using Italy's aggregate exports deflator. Bilateral imports data were deflated using the partner area's aggregate exports deflators. These in turn were calculated as the ratio of aggregate exports in current USD to aggregate exports in USD at 2000 prices. Aggregate exports data come from the 2012 edition of the World Development Indicators database (World Bank, 2012). The bilateral relative price series were constructed as the ratio of aggregate exports deflators to the partners' exports deflators. Real GDP series were constructed using a similar method, by aggregating (whenever necessary) the data on GDP in USD at 2000 prices.

Before proceeding to the estimation, the logarithms of the variables were tested for the presence of unit roots. We followed the strategy proposed by Elder and Kennedy (2001), which exploits the information provided by the observed pattern of the data This avoids on the one hand the possible loss of power caused by an incorrect specification of the deterministic component of the data generating process (Campbell and Perron, 1991), and on the other hand the multiple testing issues that affect general-to-specific testing procedures (such as Dolado et al., 1990). Elder and Kennedy's intuition is straightforward: when performing a unit root test, the researcher should rule out those alternatives that are incompatible with the observed behaviour of the data. For instance, it is pointless to test for unit roots against a trend stationary alternative (i.e., to include a linear deterministic trend in the auxiliary regression), if the observed data are not trending.

\footnotetext{
${ }^{9}$ Since the ITCS database starts in 1988, its series were retropolated back to 1970 using the rates of change of the corresponding time series provided by the 2008 version of the CHELEM database (CEPII, 2008), that reports data from 1967 to 2007. The homogeneity between the two datasets was tested by calculating the correlation coefficient between the rates of change of each couple of corresponding series in the overlapping sample (1988-2007). We considered the rates of change to avoid spurious correlation issues. The estimated correlations range from a minimum of 0.772 (exports to the BRIC) to a maximum of 0.995 (imports from OPEC), with an average of 0.92 . The data provided by the two databases are therefore substantially homogeneous, which is to be expected, since they are constructed starting from the same national sources.
} 
Starting from this intuition, Elder and Kennedy propose a one-step testing strategy based on Dickey and Fuller's (1981) $\Phi_{1}$ and $\Phi_{3}$ likelihood ratio statistics, depending on the presence of a trend (the Appendix provides a detailed description). A limit of Elder and Kennedy's approach is that they do not consider the implications of structural breaks for the observed behaviour of the data. For instance, the data could not be trending over the whole sample because of the presence of a segmented trend. Due to this reason, we supplemented Dickey and Fuller's (1981) tests with Zivot and Andrews's (1992) and Lee and Strazicich's (2003) tests, that accounts for the presence of one or two breaks in the linear trend under the alternative hypothesis, respectively.

Table 4 summarizes the results. ${ }^{10}$ Rejections of the unit root null are rare, and strongly significant in only three cases: the real exchange rate towards the EZ core (variable $R_{1, t}$ ), which exhibits a single trend reversal in 1993; the imports from OPEC countries (variable $M_{5, t}$ ), which presents a doubly segmented trend (in 1978 and 1998); the exports towards the BRICS (variable $X_{6, t}$ ), which also present a doubly segmented trend (in 1975 and 1997). The break in $R_{1, t}$ suggests that the reversal in Italy's real effective exchange rate observed in Table 3 might depend largely on its relations with the core EZ countries, in the light of the developments following the 1992 EMS crisis. However, whether and how this reversal has significantly affected Italy's external constraint depends in turn on the size of the estimated elasticities (in particular, $\psi_{1}$ and $\eta_{1}$; see Eq. 3). Summing up, the results of the unit root tests warrant the adoption of a cointegration estimator.

\subsection{Cointegration Estimates in the Presence of Structural Breaks: Methods and Results}

The evaluation of the generalized Bop constraint required the estimation of 14 long-run equations (an imports equation and an exports equation for each of the seven trade partners). Since our sample includes many major shocks (the fall of the Bretton Woods system, the two oil shocks, the inception of the EMS and of the euro, the 1992-1993 EMS crisis, and so on), the long-run parameters of our equations could undergo breaks at some unspecified point of the sample. As Gregory and Hansen (2006) points out, this may undermine the power of cointegration tests, leading to under-rejection of the non-

${ }^{10}$ When repeated with differenced variables, the tests consistently rejected the unit root null, which implies that non-rejection for the series in level means presence of a single unit root. Detailed results available upon request. 
cointegration null. In order to cope with this issue, whenever the hypothesis of noncointegration was not rejected, we verified whether this non rejection could be determined by the presence of structural breaks, testing for the absence non-cointegration using two procedures that account for shifts in the estimated parameters.

The testing strategy adopted can be explained using the following model:

$$
y_{t}=\alpha_{0}+\alpha_{1} D_{1 t}+\alpha_{2} D_{2 t}+\boldsymbol{\beta}_{0}{ }^{\prime} \mathbf{x}_{t}+\boldsymbol{\beta}_{1}{ }^{\prime} D_{1 t} \mathbf{x}_{t}+\boldsymbol{\beta}_{2}{ }^{\prime} D_{2 t} \mathbf{x}_{t}+u_{t}
$$

where lower cases indicate logarithms, the $\alpha_{i}$ are scalar parameters, the $\boldsymbol{\beta}_{i}$ are vectors of parameters, $\mathbf{x}_{t}$ is the vector of the explanatory variables, $u_{t}$ is the residual, and $D_{1 t}$ and $D_{2 t}$ are the 'shift' dummy variables used to represent the structural breaks, defined as follows:

$$
\begin{aligned}
& D_{1 t}= \begin{cases}0 & \text { if } t \leq\left[n \tau_{1}\right] \\
1 & \text { if } t>\left[n \tau_{1}\right]\end{cases} \\
& D_{2 t}= \begin{cases}0 & \text { if } t \leq\left[n \tau_{2}\right] \\
1 & \text { if } t>\left[n \tau_{2}\right]\end{cases}
\end{aligned}
$$

where $\tau_{1} \in(0,1)$ and $\tau_{2} \in(0,1)$ describe the relative timing of the break points, and the square brackets denote the integer part. Taking Equation (4) as a reference, we proceeded from 'specific to general' in three steps. First, we consider the particular case in which $D_{1 t}=0 D_{2 t}=0$. In this case, Equation (5) coincides with a standard cointegrating relation (with no breaks). In this case yhe null of non-cointegration was tested using the 'Cointegrating Residual Augmented Dickey Fuller' $(C R A D F)$ test by Engle and Granger (1987), and in case of rejection, the estimated elasticities, $\hat{\boldsymbol{\beta}}_{\mathbf{0}}$, were taken as the relevant long-run parameters.

In case of non-rejection, we moved to the particular case in which only $D_{2 t}=0$, i.e., to Gregory and Hansen's (2006) model, which accounts for the presence of a structural break at an unknown date. ${ }^{11}$ The test statistics is evaluated as $\inf _{\tau_{1}} \operatorname{CRADF}\left(\tau_{1}\right)$, i.e., as the smallest (largest in absolute value) among the CRADF statistics evaluated in

${ }^{11}$ Gregory and Hansen's procedure allows also for the presence of a shift in the intercept only (from $\alpha_{0}$ to $\alpha_{0}+\alpha_{1}$ ). Whenever this was enough to reject the non-cointegration null, we preferred this "intercept shift" alternative, as it allowed us to keep the parameterization of the model as parsimonious as possible. 
correspondence of every possible sample split. If the test rejects the null, the estimated long-run elasticities are $\hat{\boldsymbol{\beta}}_{\mathbf{0}}$ up to the break date, and $\hat{\boldsymbol{\beta}}_{\mathbf{0}}+\hat{\boldsymbol{\beta}}_{1}$ afterwards.

If even this test fails to reject, we apply the general case where both the shift dummies are free to vary (Hatemi-J, 2008). The test statistics is evaluated as $\inf _{\tau_{1}, \tau_{2}} C R A D F\left(\tau_{1}, \tau_{2}\right)$. As a consequence, if the test rejects the null of non cointegration, the estimated elasticities are $\hat{\boldsymbol{\beta}}_{\mathbf{0}}$ up to the first break date, $\hat{\boldsymbol{\beta}}_{\mathbf{0}}+\hat{\boldsymbol{\beta}}_{1}$ up to the second break date, and $\hat{\boldsymbol{\beta}}_{\mathbf{0}}+\hat{\boldsymbol{\beta}}_{1}+\hat{\boldsymbol{\beta}}_{2}$ up to the end of the sample.

The results of the testing procedure are summarized in Table 5. Cointegration without structural breaks was found in only three out of fourteen cases (imports from OPEC and exports to OPEC and BRIC). In only two cases we found evidence of a double break (imports from the EZ core and periphery). The estimated break dates are in general easy to interpret. For instance, four out of the thirteen breaks fall in the 1985-1986 biennium, just before the onset of the Single Market and of the "credible" EMS (see Frankel and Phillips, 1992), the break in the imports from the BRIC falls in correspondence of China's entry into the WTO, three other breaks occur around the 1992-93 crisis, and so on. Table 6 reports the estimated elasticities. The income elasticities are strongly significant (with the only exception of the elasticities of imports from OPEC). The price elasticities are rightly signed and strongly significant in the exports equation. In the imports equation they sometimes take the wrong sign in some subsample, but when this happens they mostly turn out to be not statistically significant.

\section{Economic Analysis}

\subsection{Thirlwall's Law and Italy's Decline}

The estimated elasticities (Table 6), were used to calculate Italy's Bop-constrained growth rate (3) over the sample ranging from 1970 through 2010. In case of regime change, each elasticity was multiplied for the sample average of the relevant explanatory variables, taken over the corresponding regime. ${ }^{12}$ By applying consistently this procedure

${ }^{12}$ Consider for instance the income elasticity of exports to partner 4 , namely $\varepsilon_{4}$. This parameter changes after 1985, going from 3.13 to 1.70 (Table 5). As a consequence, the corresponding 'partner growth' effect in the numerator of Equation (3), $v_{4} \varepsilon_{4} \dot{Y}_{4}$, was evaluated as $0.120 \times 3.13 \times 0.031=0.012$ up to 
we obtain a time-varying BoP-constraint. The calculations are summarized in Table 7 , which reports separately the 'price effect' featuring in the numerator of Equation (3), given by $\sum_{j=1}^{7} \dot{R}_{j}\left[\mu_{j}\left(1-\psi_{j}\right)-v_{j} \eta_{j}\right]$; the 'quantity effect', given by $\sum_{j=1}^{7} v_{j} \varepsilon_{j} \dot{Y}_{j}$; the denominator of Equation (3), given by $\sum_{j=1}^{7} \mu_{j} \pi_{j}$; the BoP-constrained rate, i.e., the ratio of the first two effect to the third; the actual real growth rate; and the long-run real growth rate. The latter was evaluated by subtracting from the actual growth rate its cyclical component, which in turn was evaluated using two alternative filtering procedures: the usual Hodrick and Prescott (1997) filter, and the Christiano and Fitzgerald (2003) bandpass filter. ${ }^{13}$

The moving pattern of the generalized constraint is represented in Figure 5, along with the patterns of the constraint's numerator and denominator.

Over the whole sample, Italy has complied with its Bop-constraint: the sample averages of the actual growth rate and of the Bop-constrained rate are almost identical (Table 7, last row). ${ }^{14}$ However, rather than the averages over the whole sample, it is the time profile of the constraint (and of the actual long-run growth) that provides interesting insights on the developments of the Italian economy.

Looking at the patterns reported in Figure 5, a striking feature is that the BoP constraint becomes increasingly tight over time, by declining almost monotonically over the whole sample period. This feature suggests that the observed decline in Italy's growth rate could actually be determined by a progressive tightening of its Bop constraint (possibly with the cumulative effects envisaged by the KDT model). Two major negative shocks are especially evident, both followed by a slowdown in the pace of labour productivity growth: the first one in the mid-Eighties, where $\dot{Y}_{B P}$ drops from $2.8 \%$ in 1985 to $2.2 \%$ in

1985 (where 0.120 is the 'other European countries' average exports market share and 0.031 is their average real growth rate from 1970 to 1985 ) and as $0.124 \times 1.70 \times 0.021=0.004$ from 1986 on (where 0.124 and 0.021 are the average exports market share and real growth rate from 1986 to 2010).

${ }^{13}$ Following Ravn and Uhlig (2002) suggestion, the degree of smoothness $\lambda$ of the Hodrick-Prescott filter was set equal to 6.25. As for the Christiano-Fitzgerald filter, its asymmetric version was used to remove the cyclical components with period of oscillation comprised between 2 and 8 years (following the standard definition of business cycle that goes back to Burns and Mitchell, 1946).

${ }^{14}$ The respect of the Bop constraint does not imply per se that a country's growth equals that of its productive potential. In fact, actual growth may respect the constraint, while being below the growth of productive potential (Thirlwall, 2001). I thank an anonymous referee for this observation. 
1987; the second one after the 1992 crisis, where $\dot{Y}_{B P}$ drops further from $2.2 \%$ in 1992 to $1.0 \%$ in 1997. In both cases, the reduction in the Bop constraint occurs in correspondence to a commitment towards a more rigid 'monetary union', first within the so-called 'credible EMS', then with the struggle to enter the Euro. However, as Table 7 and Figure 5 show, the two episodes differ because in the first case ('credible EMS') the tightening of the Bop constraint was due to a drop in the numerator, determined largely by a reduction in the 'quantity' effect (the second summation in the denominator of Equation (3)), while in the second case ('struggle for Euro') the drop in $\dot{Y}_{B P}$ followed an increase in its denominator. A closer look at the data shows that in the ' 80 s the reduction in the numerator was driven by a reduction in the elasticity of exports towards the 'Northern' European countries, both those of the EZ core (where the reduction occurred in 1987; see Table 5), and the other European countries (where the break occurred in 1986). This structural break, possibly determined by a loss of non-price competitiveness of Italian products, interacted with the downward trend in the partners real growth rates (apparent in Table 1 and Figure 1), thus determining a sudden tightening of Italy's external constraint by 0.6 percentage points between 1985 and 1987, followed by a productivity slowdown starting in 1989 (Figure 2). On the contrary, the increase in the denominator of Equation (3) that occurred in the '90s, signalling an increase in Italy's dependence from foreign goods and services, was mostly due to an increase of the income elasticity of imports from the core EZ and the rest of the world (Table 5), reinforced by a negative price effect determined by real appreciation towards the EZ core.

Figure 6 represents the long-run growth series with the generalized constraint (3). The long-run component of Italian real growth follows closely the Bop constraint, with a correlation coefficient equal to 0.78. Figure 6 shows that since the beginning of the Seventies Italy has alternated periods in which the constraint was violated, with periods in which it was respected, following a pattern that is consistent with some major stylized facts, and in particular with the pattern of Italy's external indebtedness (Figure 7). Starting from a position close to the constraint in 1971, the long-run growth rate violates strongly the constraint in the first half of the Seventies: this is consistent with a quick worsening of Italy's net foreign asset position, from about 4\% in 1970 to about $-4 \%$ in 1976. After the crises occurring in the second half of the Seventies, the long-run growth of Italy moves below the constraint and respects it until 1985, then violates it again during the 'credible 
EMS' period, from 1986 to the eve of 1992 crisis, when the net foreign asset-to-GDP ratio worsens further by 5 to 6 percentage points, according to the sources of data. The 1992 crisis brings again actual growth. below the Bop constraint: this is reflected by an improvement in the net foreign asset. Starting in 1995, Italy's long-run growth rate violates again the constraint for almost a decade. As a consequence, the net foreign asset position experiences another turning point, and set itself on a decreasing trend, that lasted at least until 2010.

This patterns shows that the two major crises of the Italian economy in the last four decades (1992 and 2011) have been anticipated by a sudden tightening of the external constraint, followed by a productivity slowdown that set the long-run growth rate on a lower path, thereby inducing a more or less protracted violation of the Bop-constraint, leading to an accumulation of net external liabilities, followed by a balance-of-payments crisis. The tightening of the external constraint in the mid-'90s was twice as large as the one occurring in the mid-' 80 s (1.2 and 0.6 percentage points respectively), and was not followed by a major realignment in the Italian real exchange rate towards its major trade partners. This may explain why the productivity slowdown since 1995 has been so persistent, unlike the one experienced from 1989 to 1992.

\subsection{Assessing the Trade Partners' Contribution to Italy's Decline and Financial Crisis}

Despite the widespread claim that Italy has incurred in a 'sovereign debt' crisis, the data show that in the period from the inception of the euro to the financial crisis, Italian public debt-to-GDP ratio had been falling (from $114 \%$ in 1999 to $104 \%$ in 2007), while Italian net external liabilities-to-GDP ratio had been rising (from $7 \%$ in 1999 to $21 \%$ in 2007). There is therefore enough evidence to support the view that in Italy, as in the other EZ peripheral countries, the crisis was triggered by the accumulation of private (net) external liabilities, a point of view which is nowadays shared even by prominent ECB officials such as Constâncio (2013). As we have shown in the previous section, the last reversal in Italy's pattern of external indebtedness, as well as the last slowdown of its labour productivity, both coincide with the tightening of its external constraint occurring between 1994 and 1997, after which Italy's long-run growth has violated the Bop constraint for almost a decade, paving the way to its current financial crisis. This suggests that the roots of the current Italian crisis can be traced back to the mid-'90s, when the 
Bop constraint tightened by more than one percentage point. It is therefore interesting to look at this break in the external constraint more closely, by examining the contribution to it of the different trade partners and channels of transmission. This can be done by looking at the derivatives of the generalized constraint, which allow us to linearize the constraint behaviour around a given change point.

We performed this analysis by considering the 1980-2010 sample, which corresponds to the Italian experience within the 'enlarged Deutsche mark zone' (first as EMS, then as EZ). We split the sample in two half, taking 1995 as the last date of the first regime, and we calculated the Bop in the two subsamples 1980-1995 and 1996-2010, taking the sample averages of all the relevant variables (including the elasticities). This exercise is summarized in Table 8. Some interesting features emerge from the data: the Bop constraint provides a reasonable approximation of the average growth rate in both subsamples; in both subsamples Italy seems to have grown slightly above its Bop constraint (a feature that is consistent with the trend in its external indebtedness); moreover, the drop in the actual growth rate between the two subsamples (equal to 1.3 percentage points) coincides with the tightening of the Bop constraint (also equal to 1.3 percentage points; see the last two rows of Table 8). This confirms that the extended Thirlwall's tracks the evolution of the Italian long-run growth fairly well.

In order to investigate in detail the determinants of the structural change in the BoP constraint we decompose this change using the following Taylor expansion:

$$
\begin{aligned}
& \Delta \dot{Y}_{B P}=\sum_{j=1}^{7}\left[\Delta \dot{Y}_{j} \frac{\partial \dot{Y}_{B P}}{\partial \dot{Y}_{j}}+\Delta \dot{R}_{j} \frac{\partial \dot{Y}_{B P}}{\partial \dot{R}_{j}}+\Delta v_{j} \frac{\partial \dot{Y}_{B P}}{\partial v_{j}}+\Delta \mu_{j} \frac{\partial \dot{Y}_{B P}}{\partial \mu_{j}}+\Delta \varepsilon_{j} \frac{\partial \dot{Y}_{B P}}{\partial \varepsilon_{j}}+\right. \\
& \left.+\Delta \eta_{j} \frac{\partial \dot{Y}_{B P}}{\partial \eta_{j}}+\Delta \pi_{j} \frac{\partial \dot{Y}_{B P}}{\partial \pi_{j}}+\Delta \psi_{j} \frac{\partial \dot{Y}_{B P}}{\partial \psi_{j}}\right]+R_{1}
\end{aligned}
$$

where $\Delta$ represents the change in the variables between the two subsamples, the derivatives (Equation B5 to B12 in Appendix B) are evaluated in the first subsample, and $R_{1}$ is the remainder of the approximation. This decomposition allows us to measure the (linear) effect of each partner area's variable (real growth, real exchange rate) and structural parameters (market shares and elasticity) on the constraint. The 56 elements of the decomposition (5) are summarized in Table 9, where we express them as a percentage of the Bop-constrained rate decrease (this implies that negative contributions lift the 
constraint $u p$ ). Table 9 allows us to rank the different (gross) contributions by partner area as well as by channel of transmission. The last column (row totals) lists the partners' net contributions, while the last row (column total) lists the net effect of each channel of transmission.

Looking at the last column, the largest gross contribution to the 1.3 percentage points decrease of Italy's Bop-constrained growth comes from the EZ 'core' countries (about $44 \%$ ), followed by the rest of the World (39\%), and by OPEC countries (21\%). The only partner area that contributed to loosen the constraint was the EZ 'periphery', mostly through an 'export income elasticity' effect. ${ }^{15}$ As showed by Equation (B9), this effect, in turn, depends on real growth and the export market share. This results indicate that during the euro experience Italy has been able to benefit to some extent of the peripheral countries growth, which in turn was inflated by foreign capital inflows (Constâncio, 2013). However, the beneficial contribution of 'peripheral' countries is smaller than the detrimental contribution of the 'core' countries. As a consequence, trade with the EZ as a whole has contributed to about a fourth of the tightening of Italy's Bop constraint. Looking at the last row, the two most important factors affecting Italy's Bop constraint have been an increase in the income elasticity of imports (this increased 'appetite for imports' contributes for $54 \%$ to the tightening of the constraint), and the adverse evolution of relative prices, i.e., Italy's real exchange rate appreciation (that contributes for $32 \%$ ), whereas the two major offsetting channels of transmission where the export income elasticity effect described above (which loosened the constraint by about 16\%), and the export market share effect, mostly due to an increase in the export market share towards relatively fast growing areas such as the EZ periphery and the emerging countries in the BRIC group and in the rest of the World.

Going into some more detail, and looking at the individual table entries, we can see that the large EZ 'core' contribution (44\%) is determined by two effects: a 'growth' effect (that accounts for 12\%) and an 'imports income elasticity' effect (that accounts for another $16 \%$ ). In fact, core EZ growth slowed down by 0.5 percentage points between the first and second subsample (see the first row of Table 8). Since core countries are the first

${ }^{15}$ Since the income elasticity of exports towards EZ peripheral countries underwent a change in 1986 (Table 5), its average increased by 0.14 between the first and the second subsample. 
market for Italian exports, repressed growth in core countries had a large impact on Italian Bop constraint.

Another interesting feature emerging from the Table is that about a half $(16 \%)$ of the large 'relative prices' effect $(32 \%)$ is determined by trade with OPEC countries. It is worth noting that on average Italy has depreciated against those countries: the relative prices growth rate went from $10 \%$ in the first subsample to $-4 \%$ in the second subsample. However, since imports from OPEC countries are relatively inelastic to prices, the bilateral Marshall-Lerner conditions are not met. This implies that the negative 'pure terms of trade' effect of the real devaluation outweighed its 'volume effect', thus dragging down the Bop constraint. Even this result conflicts with another mantra, namely, that the strength of the euro, despite its depressing effect on the peripheral countries net exports, has contributed to relieve these countries from the burden of their 'energy bill'.

\section{Conclusions}

A large body of literature traces back the relative decline of the Italian economy within the EZ to a fall in the rate of growth of its labour productivity, occurring quite sharply in the mid-'90 (Figure 2). The supply-side explanations of this major stylized fact are not consistent with its size and timing. In this paper, we provide an alternative explanation, grounded on the Kaldor-Dixon-Thirlwall growth model (Thirlwall, 2002, Chap. 4). Its main message is that a country's productivity growth rate may be pushed on a persistently lower path by a major shock coming from its external constraint. In order to verify this hypothesis, we analysed the evolution of Italy's Bop-constraint from 1970 to 2010, using a generalized version of Thirlwall's (1979) model. Our extended model allows us to examine the contribution to the Bop constraint, hence to the 'sustainable' rate of long-run growth, of each partner country/area, through several transmission mechanisms. The estimation methodology takes into account the possible existence of up to two structural breaks in the long-run elasticities, thus allowing us to define a 'moving' Bop constraint. This moving constraint explains fairly well the decline in the Italian long-run growth rate. The major financial crises of the Italian economy (occurring in 1992 and 2011) appear to have been preceded by a sudden tightening of the constraint, followed by a slowdown of labour productivity growth, after which Italy's actual growth exceeded its sustainable (BoP-constrained) value, leading to the accumulation of net external liabilities, followed 
by an external accounts crisis. Despite this analogy, the two episodes of external constraint tightening differ both in their size and in their nature. The tightening occurred in the mid-' 80 s was shown to depend mostly on a loss of non-price competitiveness towards the Northern European countries, while the tightening occurred in the mid-' $90 \mathrm{~s}$, which was twice as large as the previous one, depended on an increase in the dependence from foreign goods and services coming from the core EZ and the 'rest of the World' countries, reinforced by the negative effect of a real exchange rate appreciation towards the core EZ. The core countries large 'imports income elasticity' effect can be traced back to two structural features: the large increase in this elasticity $(+0.68$ between the first and the second subsample, see Table 8), and the fact that 'core' EZ corresponds to the largest imports market share.

We examined in particular the second tightening of the constraint, occurring in the mid'90s, whose effects on labour productivity were more persistent, by decomposing the overall reduction in the long-run growth rate (equal to 1.3 percentage points) across the different partner areas and channels of transmission. Besides the contribution of the core EZ countries, we found that another important contribution came from OPEC countries and in particular from the relative prices effect, thus stressing the role of the 'energy bill' in dragging down Italy's long-run growth. Trade with the EZ peripheral countries contributed to lift up Italy's Bop constrained, but this effect was unable to offset the negative contribution from the core countries, and the EZ net contribution to Italy's longrun growth was therefore negative, despite the widespread claims that core countries (and Germany in particular) are the growth engine of the peripheral economies (among which Italy).

This evidence should be contrasted with the repeated statement that core countries, and in particular Germany, have been an engine of growth for peripheral countries. In fact, the results of our analysis seem to be more consistent with the hypothesis that after the onset of the euro Germany practised a policy of competitive 'internal' devaluation, by depressing its real wage growth in order to enhance its price competitiveness, thus depressing internal consumption and imports, following a mercantilist model of development that has dragged down growth in the EZ periphery (Cesaratto and Stirati, 2010). In a similar vein, our results contradict another mantra of the current political debate in Italy (and Europe as large), namely, that Italy's and EZ peripheral growth is 
depressed because unfair price competition from the BRIC economies. The impact of BRIC economies on Italy's Bop constraint is negligible, as is to be expected, since the market share of these countries, though rising, is still relatively small. Moreover, BRIC countries on average have depreciated in real terms (Table 8), and Italy has been able to expand its export market share in these countries (with a beneficial effect on its external constraint), hence the role of their 'unfair' price competition should be toned down in the current discussion.

To the extent that the analysis presented in this paper supports the Kaldor-DixonThirlwall demand-led explanation of long-run growth, it leaves open the question about how a positive demand shock could be engineered that would push Italy again on its previous labour productivity growth pattern. Figure 2 shows that after the exchange rate realignment following the 1992 financial crisis, the Italian productivity resumed its trend, but stopped shortly before, in 1995. Moreover, the exchange rate realignment had no effect on the external constraint, which tightened further by about one point. This pattern depends on two stylized facts. First, the exchange rate realignment was only temporary, partly undone by the revaluation in 1995, and followed by the most prolonged period of steady nominal and real appreciation against its most important trade partners ever experienced by the Italian domestic currency after WWII. The structure of Equation (3) shows that only sustained variations in the real exchange rate may exert an effect on longrun growth. ${ }^{16}$ Moreover, the 1992-1993 realignment, besides being temporary, was also accompanied by an increase in the dependence of Italy from foreign imports.

The latter feature makes it clear that any perspective of relieving the Italian economy by domestic demand expansion, obtained possibly by begging for Brussels mercy on the Stability Pact parameters, is doomed to be illusory. Owing to the structure of income import elasticities and of the trade market shares, an uncoordinated domestic demand expansion would bring the Italian growth rate once more above its BoP-constrained level, paving the way to a further financial crisis. Building on the previous analysis, three factors would exert a positive effect on the BoP-constraint, lifting it up: (i) a reversal of the domestic demand repression policy practised by Northern countries (Cesaratto and Stirati, 2011); (ii) a reversal of the real appreciation trend of the Italian domestic currency against its main trade partners (see for instance Table 8); (iii) a reduction of Italy's structural

\footnotetext{
${ }^{16}$ In other words, only persistent changes in $\dot{R}$, not in $R$, have an impact on long-run growth.
} 
dependence on foreign goods and services. At present, these three measures are, to different extents, politically unfeasible. As for point (i), it is extremely unlikely that core EZ countries will adopt a more expansionary fiscal and (through the ECB) monetary policy stance, both because this would imply a top-down income redistribution, and because it would imply a loss on the core countries creditors' assets, both of which are not in the interest of their ruling classes. A steady depreciation of the Italian real exchange rate through nominal exchange rate realignment, as it was common practice in the first half of the ' $80 \mathrm{~s}$, is politically unfeasible because of the euro. ${ }^{17}$ At the same time, the 'internal devaluation' policies, while having limited effects on the bilateral real exchange rates towards the EZ, are crushing the Italian productive structure, thus worsening the dependence of Italy on foreign goods, services, and capitals (point (iii)), which is also fostered by the Single Market rules (e.g., the prohibition for national governments to grant a preferential treatment to national suppliers). All these elements make it extremely unlikely that in the present political and institutional framework a major positive shock to the Italian economy could be engineered, such as to bring it again on a positive labour productivity trend. Since Italy remains the second largest industrial economy in the EZ (and the third largest in size), this conclusion casts serious doubts on the sustainability of the single currency.

\section{References}

Alesina, A.F., Glaeser, E.L., Sacerdote, B. (2005) "Work and leisure in the US and Europe: why so different?”, NBER Macroeconomics Annuals, 20, 1-64.

AMECO (2013) Annual Macro-Economic Online Database, European Commission, http://ec.europa.eu/economy_finance/db_indicators/ameco/index_en.htm.

Barbieri, P., Scherer, S. (2009) "Labour market flexibilization and its consequences in Italy”, European Sociological Journal, 25, 677-692.

Belussi, F., Pilotti, L. (2002) "Knowledge creation, learning and innovation in Italian industrial districts", Geografiska Annaler, 84B, pp. 125-139.

${ }^{17}$ It is worth remembering that under the EMS exchange rate mechanisms the realignments preserved some degree of symmetry. In fact, during the ' 80 s the Deutsche Mark was realigned upward six times, and the Italian lira was realigned downward only four times (also owing to the fact that it had negotiated a wider oscillation band around the declared central parity with the ECU). 
Burns, A. F., Mitchell, W. C. (1946). Measuring Business cycles. New York: NBER.

Busetti, F., Forni, L., Harvey, A., Venditti, F. (2006) "Inflation convergence and divergence within the European Union”, ECB Working Paper Series, No. 574 (January).

Carlucci, F. (2008) L'Italia in ristagno, Milano: Franco Angeli.

Carlucci, F. (2010-11) "Stagnazione e crescita in Italia", Rivista di Politica Economica, 1-3, 155-188.

Campbell, J.Y, Perron, P. (1991) "Pitfalls and opportunities: what macroeconomists should know about unit roots", NBER Macroeconomics Annuals 1991, 141-201.

CEPII (2008) Comptes Harmonisés sur les Echanges et L'Economie Mondiale, CD-Rom version.

Cesaratto, S., Stirati, A. (2010) "Germany and the European and Global Crises," International Journal of Political Economy, 39(4), pp. 56-86Constâncio, V. (2013) "The European Crisis and the role of the financial system", speech by Vítor Constâncio, Vice-President of the ECB, at the Bank of Greece conference on "The crisis in the euro area", Athens, 23 May 2013, http://www.ecb.europa.eu/press/key/date/2013/html/sp130523_1.en.html (last Accessed August 3, 2014).

Daveri, F., Jona-Lasinio, C. (2005) "Italy's decline: getting the facts right", Giornale degli Economisti, 64, 365-410.

Daveri, F., Parisi, M.L. (2010) "Temporary workers and seasoned managers as causes of low productivity", paper presented at the Ifo, CESifo and OECD Conference on Regulation "Political Economy, Measurement and Effects on Performance", Munich, 29-30 January 2010.

Dickey, D., Fuller, W.A. (1979) "Distribution of the estimators for autoregressive timeseries with a unit root", Journal of the American Statistical Association, 74, 427431.

Dickey, D.A., Fuller, W.A. (1981) "Likelihood ratio statistics for autoregressive time series with a unit root" Econometrica 49, 1057-72. 
Dixon, R., Thirlwall, A.P. (1975) "A model of regional growth-rate differences on Kaldorian lines”, Oxford Economic Papers, 27, 201-214.

Dolado, J., Jenkinson, T., Sosvilla-Rivero, S. (1990) "Cointegration and unit roots", Journal of Economic Surveys, 4, 249-73.

Elder, J., Kennedy, P.E. (2001) "Testing for unit roots: what should students be taught?" Journal of Economic Education 32, 137-146.

Engle, R. F., \& Granger, C. W. (1987). Co-integration and error correction: representation, estimation, and testing. Econometrica: journal of the Econometric Society, 251-276.

Frankel, Jeffrey \& Phillips, Steven, 1992. "The European Monetary System: Credible at Last?,” Oxford Economic Papers, Oxford University Press, vol. 44(4), pages 791816 , October.

Gordon, R.J., Dew-Becker, I. (2008) "The role of labor market changes in the slowdown of European productivity growth", CEPR Discussion Papers, February.

Gregory, A.W., Hansen, B.E. (1996) "Residual-based tests for cointegration in models with regime shifts", Journal of Econometrics 70, 99-126.

Hatemi-J, A. (2008) "Tests for cointegration with two unknown regime shifts with an application to financial market integration”, Empirical Economics, 35, 497-505.

Robert J. Hodrick \& Edward Prescott, 1981. "Post-War U.S. Business Cycles: An Empirical Investigation," Discussion Papers 451, Northwestern University, Center for Mathematical Studies in Economics and Management Science.

Hodrick, R.J., Prescott, E.C. (1997) "Postwar U.S. Business Cycles: An Empirical Investigation," Journal of Money, Credit, and Banking, 29, 1-16.

IMF (2010) International Financial Statistics, 2010\#12 CD-Rom edition.

IMF

World

Economic

Outlook

Database, http://www.imf.org/external/pubs/ft/weo/2012/02/weodata/index.aspx.

IMF (2014) World Economic Outlook Database, http://www.imf.org/external/pubs/ft/weo/2014/02/weodata/index.aspx. 
Kaldor, N. (1970) “The case for regional policies”, Scottish Journal of Political Economy, 17, 337-348.

Lane, P.R., Milesi-Ferretti, G.M. (2007) "The external wealth of nations mark II", Journal of International Economics, 73, 223-250.

Lewney, R., Claussen, J., Hay, G., Kyriakou, E., Vieweg, G. (2012) "The cost competitiveness of European industry in the globalisation era - Empirical evidence on the basis of relative unit labour costs (ULC) at sectoral level", Industrial Policy and Economic Reform Papers, 15, 1-111.

McCombie, J.S.L., Pugno, M., Soro, B. (eds) (2002) Productivity Growth and Economic Performance: Essays on Verdoorn's Law, London: MacMillan.

Pierluigi Montalbano \& Silvia Nenci, 2011. "Are the Emerging Economies a Threat to the Italian Competitiveness?," QA - Rivista dell'Associazione Rossi-Doria, Associazione Rossi Doria, issue 4, December.

OECD (2013) OECD Statistics Extracts, http://stats.oecd.org/Index.aspx.

Ofria, F., Millemaci, E. (2010) “Kaldor-Verdoorn’s law and increasing returns to scale; a comparison across developed countries", MPRA Paper, No. 3941.

Parisi, M.L., Schiantarelli, F., Sembenelli, A. (2006) "Productivity, innovation and R\&D: micro evidence for Italy", European Economic Review, 50, 2037-2061.

Pastore, F. (2010) "Assessing the impact of incomes policy: the Italian experience", International Journal of Manpower, 31, 793-817.

Pyke, F., Sengerberger, W. (eds) (1992) Industrial districts and local economic regeneration, Geneva: International Institute for Labor Studies.

Rabellotti, R., Carabelli, A., Hirsch, G. (2009) "Italian industrial districts on the move: where are they going?", European Planning Studies, 17, 19-41.

Ramazzotti, P. (2010) "Industrial districts, social cohesion and economic decline in Italy”, Cambridge Journal of Economics, 34, 955-964.

Morten O. Ravn \& Harald Uhlig, 2002. "On adjusting the Hodrick-Prescott filter for the frequency of observations," The Review of Economics and Statistics, MIT Press, vol. 84(2), pages 371-375. 
Sciulli, D. (2006) "Making the Italian labour market more flexible: an evaluation of the Treu reform", UC3M Working Papers in Economics, 2006-08.

Thirlwall, A.P. (1979) "The balance of payments constraint as an explanation of international growth rate differences", Banca Nazionale del Lavoro Quarterly Review, 128, 45-53.

A. P. Thirlwall, 2001. "The Relation between the Warranted Growth Rate, the Natural Rate, and the Balance of Payments Equilibrium Growth Rate," Journal of Post Keynesian Economics, M.E. Sharpe, Inc., vol. 24(1), pages 81-88, October.

Thirlwall, A.P. (2003) The nature of economic growth - An alternative framework for understanding the performance of nations, Cheltenham, Northampton: Edward Elgar.

Hans-Michael Trautwein \& Finn Marten Körner, 2014. "German Economic Models, Transnationalization and European Imbalances," ZenTra Working Papers in Transnational Studies 28 / 2014, ZenTra - Center for Transnational Studies, revised Jan 2014.

Verdoorn, P.J. (1949) "Fattori che regolano lo sviluppo della produttività del lavoro", L'Industria, 1, translated in Pasinetti, L. (ed.) Italian Economic Papers, vol. II, Oxford: Oxford University Press, 1993.

Wilson, T. (1976). Effective devaluation and inflation. Oxford Economic Papers, 28(1), $1-24$. 


\section{Appendix: Elder and Kennedy's (2001) Procedure for Unit Root Testing}

The results of unit root tests are strongly dependent on the choice of the deterministic component (drift and trend), whose misspecification may entail a loss of power. The testing strategy proposed by Elder and Kennedy (2001), based on Dickey and Fuller's (1981) likelihood ratio tests, exploits the a priori information provided by the pattern of the time series, in order to rule out specification of the deterministic component inconsistent with the observed behavior of the data. This allows the researcher to decide on both the correct specification of the deterministic component and the presence of a unit root using a single test, thus reducing the multiple hypotheses testing issues presented by other testing strategies.

First, the plot of the series is inspected, in order to verify whether it exhibits a linear trending behavior. If the series is trending, we perform an $F$ test for the null hypothesis $H_{0}: \rho=1, \beta=0$ in the model:

$$
y_{t}=\alpha+\beta t+\rho y_{t-1}+\varepsilon_{t}
$$

The $F$ statistic is compared with the critical values of the $\Phi_{3}$ statistic provided (Dickey and Fuller, 1981). Failure to reject the null implies that the series is $I(1)$ with drift. The rejection can occur against three possible alternatives:

- I(0) without trend $(\rho<1, \beta=0)$, which can be ruled out if the observed series is trending;

- I(1) with trend $(\rho=1, \beta \neq 0)$, which can be ruled out because it would imply a quadratic trend in the time series;

- I(0) with trend $(\rho<1, \beta \neq 0)$, which is the only alternative compatible with the observed behavior of the data.

If instead the series does not display a trending behavior, we test the null hypothesis $H_{0}: \rho=1, \alpha=0$ in the model

$$
y_{t}=\alpha+\rho y_{t-1}+\varepsilon_{t}
$$

where the $F$ statistics follows the $\Phi_{1}$ distribution by Dickey and Fuller (1981). Failure to reject implies that the series is $I(1)$ without drift. Once again, rejection can occur against several alternatives:

- $I(0)$ with zero unconditional mean $(\rho<1, \alpha=0)$, which is unlikely, ${ }^{18}$

\footnotetext{
${ }^{18}$ While the data available could still be centered on their sample mean, the probability that the unconditional mean of the population is zero is equal to zero.
} 
- I(1) with drift $(\rho=1, \alpha \neq 0)$, which is inconsistent with the observed behavior of the data, because such a DGP would bring about a trending behavior;

- $I(0)$ with non-zero unconditional mean $(\rho<1, \alpha \neq 0)$, which therefore turns out to be the only alternative compatible with the observed behavior of the data. ${ }^{19}$

In both cases, we resort to the augmented version of the tests, by adding to the equation lags of the differenced dependent variable in order to whiten its residuals. The lag length was determined by reduction, starting from a maximum order of lags equal to 2 , which was deemed appropriate considering the sample length and the fact that we are using annual data.

It is worth noting that in principle a non-trending behavior does could depend on the presence of structural breaks in the linear trend, rather than on the absence of a linear trend. For this reason we supplemented the Elder and Kennedy procedure with two tests that allow for the presence of structural breaks: Zivot and Andrews (1992), for the null of unit root against the alternative of a segmented trend, and Lee and Strazicich (2003) test, which accounts for the presence of two breaks. This double check allows us to verify that we did not misunderstood the nature of the underlying DGP. ${ }^{20}$

${ }^{19}$ Elder and Kennedy provide also a strategy for dealing with ambiguous cases, i.e., those cases in which an inspection of the data does not provide a clear cut intuition on their behavior. We did not find such cases in our sample, because the trade and GDP series were all trending (due to economic growth and the progressive opening to international trade), while the relative prices series did never exhibit a trending behavior over the whole sample, for the reasons discussed in Section 3.

${ }^{20} \mathrm{I}$ thank an anonymous referee for this suggestion. 


\section{Tables}

Table 1. Some stylized facts on the Italian decline

\begin{tabular}{lllll}
\hline & Eurozone & Core & Italy & Periphery \\
\hline Average real growth & & & & \\
\hline 1960 & 5.3 & 4.9 & 5.7 & 7.1 \\
1970 & 3.4 & 3.3 & 3.8 & 4.0 \\
1980 & 2.4 & 2.4 & 2.4 & 2.7 \\
1990 & 2.3 & 2.1 & 1.6 & 3.2 \\
2000 & 1.3 & 1.2 & 0.4 & 2.0 \\
\hline Average growth of real per capita GDP & & & & \\
\hline 1960 & 4.4 & 4.0 & 5.0 & 6.3 \\
1970 & 2.8 & 2.9 & 3.3 & 2.9 \\
1980 & 2.0 & 2.0 & 2.4 & 2.3 \\
1990 & 1.9 & 1.7 & 1.6 & 2.8 \\
2000 & 0.8 & 0.9 & -0.2 & 0.9 \\
\hline Source: AMECO (2013). & & & & \\
\hline
\end{tabular}

Source: AMECO (2013).

Table 2. Average growth of labour productivity (GDP per hour worked)

\begin{tabular}{llll}
\hline & France & Germany & Italy \\
\hline 1970 & 4.0 & 3.8 & 4.1 \\
1980 & 2.8 & 2.3 & 1.8 \\
1990 & 2.0 & 2.2 & 1.5 \\
2000 & 1.0 & 1.1 & 0.0 \\
\hline
\end{tabular}

Source: OECD (2013).

Table 3. The rates of depreciation and of productivity growth

\begin{tabular}{lllll}
\hline & NEER $^{\mathrm{a}}$ & REER $^{\mathrm{b}}$ & ITL/ECU $^{\mathrm{c}}$ & Average labour productivity $^{\mathrm{d}}$ \\
\hline $1970-1995$ & 4.9 & & & 2.8 \\
$1976-1995$ & 4.8 & 0.6 & 4.5 & 2.3 \\
$1996-2010$ & -1.2 & -3.5 & -0.6 & 0.3
\end{tabular}

$\overline{{ }^{a} \text { Nominal effective exchange rate; }(+) \text { depreciation, (-) appreciation. Source: IMF (2013). }}$ 
${ }^{a}$ Real effective exchange rate based on relative unit labour costs; (+) depreciation, (-) appreciation. Source: IMF (2013).

${ }^{\mathrm{c}}$ Italian lira/ECU nominal exchange rate (ITL/EUR after 1998).

${ }^{\mathrm{d}}$ OECD (2013). 
Table 4. Unit root tests on the log of the variables ${ }^{\mathrm{a}}$

\begin{tabular}{|c|c|c|c|c|c|c|}
\hline variable $^{\mathrm{b}}$ & behavior & $F^{\mathrm{c}}$ & $Z A^{\mathrm{d}}$ & & $L S^{\mathrm{e}}$ & \\
\hline$M_{1, t}$ & trending & 4.03 & -3.50 & & $-3.20^{*}$ & {$[1983,1993]$} \\
\hline$M_{2, t}$ & trending & 1.47 & -2.99 & & -2.00 & \\
\hline$M_{3, t}$ & trending & 4.66 & -4.86 & & $-3.56^{*}$ & {$[1980,1986]$} \\
\hline$M_{4, t}$ & trending & 4.04 & -1.63 & & -1.43 & \\
\hline$M_{5, t}$ & trending & 3.97 & -4.37 & & $-4.06^{* *}$ & {$[1978,1998]$} \\
\hline$M_{6, t}$ & trending & 3.99 & -3.89 & & $-3.56^{*}$ & {$[1979,1995]$} \\
\hline$M_{7, t}$ & trending & 3.76 & -3.59 & & -3.16 & {$[1998,2006]$} \\
\hline$R_{1, t}$ & non trending & 0.69 & $-5.82^{* *}$ & [1993] & -2.04 & \\
\hline$R_{2, t}$ & non trending & 0.91 & -4.16 & & -2.59 & \\
\hline$R_{3, t}$ & non trending & 1.62 & -3.82 & & -2.75 & \\
\hline$R_{4, t}$ & non trending & 1.21 & -3.29 & & -2.68 & \\
\hline$R_{5, t}$ & non trending & 3.16 & -4.01 & & -2.34 & \\
\hline$R_{6, t}$ & non trending & 3.24 & -3.51 & & -2.19 & \\
\hline$R_{7, t}$ & non trending & 0.89 & -3.64 & & $-3.13^{*}$ & {$[1985,2002]$} \\
\hline$X_{1, t}$ & trending & 3.54 & -3.34 & & -2.02 & \\
\hline$X_{2, t}$ & trending & 1.69 & -2.57 & & -1.43 & \\
\hline$X_{3, t}$ & trending & 1.39 & -3.44 & & -2.10 & \\
\hline$X_{4, t}$ & trending & 3.28 & -3.30 & & -2.14 & \\
\hline$X_{5, t}$ & trending & 4.48 & -3.18 & & -1.15 & \\
\hline$X_{6, t}$ & trending & 6.45 & -4.18 & & $-4.17^{* *}$ & {$[1975,1997]$} \\
\hline$X_{7, t}$ & trending & 1.74 & -3.98 & & -2.80 & \\
\hline$Y_{1, t}$ & trending & 4.46 & -3.76 & & -2.39 & \\
\hline$Y_{2, t}$ & trending & $6.89^{*}$ & -3.13 & & -2.03 & \\
\hline$Y_{3, t}$ & trending & 1.90 & -1.81 & & -2.16 & \\
\hline$Y_{4, t}$ & trending & 1.87 & -3.63 & & -2.13 & \\
\hline$Y_{5, t}$ & trending & 4.25 & -2.73 & & -2.20 & \\
\hline$Y_{6, t}$ & trending & 2.85 & -3.55 & & -2.74 & \\
\hline$Y_{7, t}$ & trending & $7.00^{*}$ & -3.79 & & -1.83 & \\
\hline$Y_{t}$ & trending & $7.10^{*}$ & -2.73 & & -1.41 & \\
\hline
\end{tabular}


${ }^{\text {a }}$ One asterisk indicates significance at 5\% level, two asterisks at $1 \%$ level.

${ }^{\mathrm{b}}$ The suffix 1 refers to EZ core, 2 to EZ periphery, 3 to the United States, 4 to the nonEZ OECD European countries, 5 to the OPEC, 6 to the BRIC, 7 to the rest of the world. $y_{t}$ is the $\log$ of Italian real GDP.

${ }^{c}$ Dickey and Fuller (1981) $\Phi_{3}$ and $\Phi_{1}$ unit root tests (for trending and non-trending series). d Zivot and Andrews (1992) test for the hypothesis of unit root against the alternative of segmented trend; the date of the break is reported square brackets.

${ }^{\mathrm{e}}$ Lee and Strazicich (2003) tests for the hypothesis of unit root against the alternative of doubly segmented trend; the dates of the breaks are reported in square brackets. 
Table 5. Cointegration tests ${ }^{\mathrm{a}}$

\begin{tabular}{llllll}
\hline dependent variable $^{\mathrm{b}}$ & $C R A D F^{\mathrm{c}}$ & $G H-C^{\mathrm{d}}$ & & $H^{\mathrm{f}}$ & \\
$M_{1, t}$ & -3.0 & -4.54 & & $-6.57^{* *}$ & {$[1975,1992]$} \\
$M_{2, t}$ & -2.8 & -3.77 & & $-6.35^{*}$ & {$[1978,1996]$} \\
$M_{3, t}$ & -3.2 & $-4.71^{*, \mathrm{e}}$ & {$[1981]$} & & \\
$M_{4, t}$ & -1.0 & $-7.00^{* *}$ & {$[1984]$} & & \\
$M_{5, t}$ & $-4.7^{* *}$ & & & \\
$M_{6, t}$ & -1.4 & $-5.52^{* *}$ & {$[2002]$} & \\
$M_{7, t}$ & -1.6 & $-5.38^{*}$ & {$[1994]$} & \\
$X_{1, t}$ & -2.8 & $-5.75^{* *}$ & {$[1986]$} & \\
$X_{2, t}$ & -1.4 & $-5.43^{*}$ & {$[1985]$} & \\
$X_{3, t}$ & -2.3 & $-4.98^{* *, e}$ & {$[1985]$} & \\
$X_{4, t}$ & -2.3 & $-6.88^{* * *}$ & {$[1985]$} & \\
$X_{5, t}$ & $-4.3^{* *}$ & & & \\
$X_{6, t}$ & $-4.0^{*}$ & & & \\
$X_{7, t}$ & -2.2 & $-5.13^{* *, e}$ & {$[1993]$} & \\
\hline
\end{tabular}

${ }^{\mathrm{a}}$ One asterisk indicates significance at 10\% level, two asterisks at 5\% level, three asterisks at $1 \%$ level.

b The suffix 1 refers to EZ core, 2 to EZ periphery, 3 to the United States, 4 to the nonEZ OECD European countries, 5 to the OPEC, 6 to the BRIC, 7 to the rest of the world. $y_{t}$ is the log of Italian real GDP.

${ }^{c}$ Cointegrating regression augmented Dickey-Fuller test (Engle and Granger, 1987).

${ }^{\mathrm{d}}$ Gregory and Hansen (1986) non cointegration test under the alternative of a structural break (estimated break date in square brackets).

${ }^{\mathrm{e}}$ Gregory and Hansen (1986) non cointegration test under the alternative of a shift in the intercept only (estimated break date in square brackets).

${ }^{\mathrm{f}}$ Hatemi-J (2008) non cointegration test under the alternative of two shifts of unknown date in all the regression parameters (estimated break dates in square brackets). 
Table 6. A summary of the estimated long-run elasticities ${ }^{a}$

\begin{tabular}{|c|c|c|c|c|c|}
\hline \multicolumn{3}{|l|}{ Import equations } & \multicolumn{3}{|c|}{ Export equations } \\
\hline regime change $^{\mathrm{b}}$ & $\begin{array}{l}\text { income } \\
\pi\end{array}$ & $\begin{array}{l}\text { relative prices } \\
\psi\end{array}$ & regime change & $\begin{array}{l}\text { income } \\
\varepsilon\end{array}$ & $\begin{array}{l}\text { relative prices } \\
-\eta\end{array}$ \\
\hline \multicolumn{6}{|l|}{ Eurozone core } \\
\hline 1970 & $\begin{array}{l}1.62 \\
(2.11)\end{array}$ & $\begin{array}{l}-0.36 \\
(-0.34)\end{array}$ & 1970 & $\begin{array}{l}1.86 \\
(19.75)\end{array}$ & $\begin{array}{l}-0.62 \\
(-3.77)\end{array}$ \\
\hline 1976 & $\begin{array}{l}2.29 \\
(14.23)\end{array}$ & $\begin{array}{l}-0.18 \\
(-0.68)\end{array}$ & 1987 & $\begin{array}{l}1.77 \\
(14.64)\end{array}$ & $\begin{array}{l}-1.13 \\
(-7.41)\end{array}$ \\
\hline 1993 & $\begin{array}{l}3.13 \\
(9.91)\end{array}$ & $\begin{array}{l}0.36 \\
(1.97)\end{array}$ & & & \\
\hline \multicolumn{6}{|c|}{ Eurozone periphery } \\
\hline 1970 & $\begin{array}{l}2.56 \\
(5.18)\end{array}$ & $\begin{array}{l}1.14 \\
(1.28)\end{array}$ & 1970 & $\begin{array}{l}1.86 \\
(14.04)\end{array}$ & $\begin{array}{l}-0.41 \\
(-1.14)\end{array}$ \\
\hline 1979 & $\begin{array}{l}4.10 \\
(27.12)\end{array}$ & $\begin{array}{l}0.58 \\
(1.27)\end{array}$ & 1986 & $\begin{array}{l}2.22 \\
(32.12)\end{array}$ & $\begin{array}{l}-3.73 \\
(-11.54)\end{array}$ \\
\hline 1997 & $\begin{array}{l}2.95 \\
(5.48)\end{array}$ & $\begin{array}{l}0.22 \\
(0.47)\end{array}$ & & & \\
\hline United States & & & & & \\
\hline & $\begin{array}{l}1.48 \\
(10.16)\end{array}$ & $\begin{array}{l}0.27 \\
(2.42)\end{array}$ & & $\begin{array}{l}1.77 \\
(17.23)\end{array}$ & $\begin{array}{l}-1.53 \\
(-9.56)\end{array}$ \\
\hline Other Europea & countri & & & & \\
\hline 1970 & $\begin{array}{l}2.24 \\
(24.16)\end{array}$ & $\begin{array}{l}0.69 \\
(4.90)\end{array}$ & 1970 & $\begin{array}{l}3.13 \\
(26.37)\end{array}$ & $\begin{array}{l}-2.05 \\
(-11.70)\end{array}$ \\
\hline 1985 & $\begin{array}{l}1.93 \\
(22.58)\end{array}$ & $\begin{array}{l}-0.35 \\
(-3.15)\end{array}$ & 1986 & $\begin{array}{l}1.70 \\
(26.58)\end{array}$ & $\begin{array}{l}-1.22 \\
(-10.10)\end{array}$ \\
\hline OPEC & $\begin{array}{l}-0.18 \\
(-2.11)\end{array}$ & $\begin{array}{l}0.16 \\
(3.99)\end{array}$ & & $\begin{array}{l}0.33 \\
(3.88)\end{array}$ & $\begin{array}{l}-0.71 \\
(-9.83)\end{array}$ \\
\hline $\begin{array}{l}\text { BRIC } \\
1970\end{array}$ & 3.06 & 0.24 & & 1.06 & -0.38 \\
\hline
\end{tabular}


a) Bagnai - Italy's Decline and the Balance-of-Payments Constraint a/ working papers 2016/06

\begin{tabular}{lll|lll} 
& $(24.20)$ & $(2.03)$ & & $(20.17)$ & $(-2.35)$ \\
2003 & 5.29 & -1.69 & & \\
& $(3.21)$ & $(-3.76)$ & & \\
\hline \multicolumn{2}{l|}{ Rest of the world } & & & \\
1970 & 1.87 & -0.06 & & \\
& $(21.72)$ & $(-0.44)$ & & -0.48 \\
1995 & 5.96 & 0.85 & & \\
& $(17.57)$ & $(5.31)$ & & \\
\end{tabular}

${ }^{\mathrm{a}} t$-statistics in parentheses under the coefficients.

b The "regime change" date indicates the first year of the new regime. 
Table 7. The generalized Thirlwall's law for Italy (1971-2010)

\begin{tabular}{|c|c|c|c|c|c|c|c|}
\hline & \multirow[b]{2}{*}{ Price $^{\mathrm{a}}$} & \multirow[b]{2}{*}{ Quantity $^{\mathrm{b}}$} & \multirow[b]{2}{*}{ Denominator $^{\mathrm{c}}$} & \multirow[b]{2}{*}{ Constraint $^{\mathrm{d}}$} & \multirow[b]{2}{*}{ actual } & \multicolumn{2}{|c|}{ Growth } \\
\hline & & & & & & long-run ${ }^{\mathrm{e}}$ & long-run ${ }^{f}$ \\
\hline & (a) & (b) & (c) & {$[(\mathrm{a})+(\mathrm{b})] /(\mathrm{c})$} & & & \\
\hline 1971 & -0.0085 & 0.0534 & 1.5198 & 0.0296 & 0.0182 & 0.0311 & 0.0237 \\
\hline 1972 & -0.0085 & 0.0534 & 1.5198 & 0.0296 & 0.0369 & 0.0365 & 0.0312 \\
\hline 1973 & -0.0085 & 0.0534 & 1.5198 & 0.0296 & 0.0713 & 0.0398 & 0.0363 \\
\hline 1974 & -0.0085 & 0.0534 & 1.5198 & 0.0296 & 0.0550 & 0.0389 & 0.0391 \\
\hline 1975 & -0.0085 & 0.0534 & 1.5198 & 0.0296 & -0.0209 & 0.0363 & 0.0401 \\
\hline 1976 & 0.0000 & 0.0534 & 1.8005 & 0.0296 & 0.0713 & 0.0370 & 0.0401 \\
\hline 1977 & 0.0000 & 0.0534 & 1.8005 & 0.0296 & 0.0256 & 0.0364 & 0.0389 \\
\hline 1978 & 0.0000 & 0.0534 & 1.8005 & 0.0296 & 0.0324 & 0.0355 & 0.0364 \\
\hline 1979 & -0.0003 & 0.0534 & 1.9236 & 0.0276 & 0.0596 & 0.0331 & 0.0322 \\
\hline 1980 & -0.0003 & 0.0534 & 1.9236 & 0.0276 & 0.0343 & 0.0278 & 0.0266 \\
\hline 1981 & -0.0003 & 0.0534 & 1.9236 & 0.0276 & 0.0084 & 0.0219 & 0.0208 \\
\hline 1982 & -0.0003 & 0.0534 & 1.9236 & 0.0276 & 0.0041 & 0.0186 & 0.0166 \\
\hline 1983 & -0.0003 & 0.0534 & 1.9236 & 0.0276 & 0.0117 & 0.0192 & 0.0156 \\
\hline 1984 & -0.0003 & 0.0534 & 1.9236 & 0.0276 & 0.0323 & 0.0226 & 0.0186 \\
\hline 1985 & 0.0013 & 0.0534 & 1.9378 & 0.0282 & 0.0280 & 0.0262 & 0.0247 \\
\hline 1986 & 0.0035 & 0.0498 & 1.9378 & 0.0275 & 0.0286 & 0.0292 & 0.0315 \\
\hline 1987 & 0.0018 & 0.0417 & 1.9378 & 0.0224 & 0.0319 & 0.0310 & 0.0361 \\
\hline 1988 & 0.0018 & 0.0417 & 1.9378 & 0.0224 & 0.0419 & 0.0307 & 0.0363 \\
\hline 1989 & 0.0018 & 0.0417 & 1.9378 & 0.0224 & 0.0339 & 0.0274 & 0.0314 \\
\hline 1990 & 0.0018 & 0.0417 & 1.9378 & 0.0224 & 0.0205 & 0.0222 & 0.0230 \\
\hline 1991 & 0.0018 & 0.0417 & 1.9378 & 0.0224 & 0.0153 & 0.0167 & 0.0141 \\
\hline 1992 & 0.0018 & 0.0417 & 1.9378 & 0.0224 & 0.0077 & 0.0126 & 0.0078 \\
\hline 1993 & -0.0006 & 0.0417 & 2.2523 & 0.0182 & -0.0089 & 0.0111 & 0.0060 \\
\hline 1994 & -0.0006 & 0.0417 & 2.2523 & 0.0182 & 0.0215 & 0.0128 & 0.0087 \\
\hline 1995 & -0.0030 & 0.0417 & 3.2707 & 0.0118 & 0.0283 & 0.0150 & 0.0141 \\
\hline 1996 & -0.0030 & 0.0417 & 3.2707 & 0.0118 & 0.0110 & 0.0162 & 0.0195 \\
\hline 1997 & -0.0073 & 0.0417 & 3.2957 & 0.0104 & 0.0187 & 0.0174 & 0.0224 \\
\hline 1998 & -0.0073 & 0.0417 & 3.2957 & 0.0104 & 0.0140 & 0.0183 & 0.0222 \\
\hline 1999 & -0.0073 & 0.0417 & 3.2957 & 0.0104 & 0.0146 & 0.0190 & 0.0194 \\
\hline 2000 & -0.0073 & 0.0417 & 3.2957 & 0.0104 & 0.0369 & 0.0189 & 0.0159 \\
\hline 2001 & -0.0073 & 0.0417 & 3.2957 & 0.0104 & 0.0182 & 0.0166 & 0.0133 \\
\hline 2002 & -0.0073 & 0.0417 & 3.2957 & 0.0104 & 0.0045 & 0.0136 & 0.0125 \\
\hline
\end{tabular}




\begin{tabular}{llllllll}
2003 & -0.0051 & 0.0417 & 3.6833 & 0.0099 & -0.0002 & 0.0114 & 0.0128 \\
2004 & -0.0051 & 0.0417 & 3.6833 & 0.0099 & 0.0153 & 0.0104 & 0.0126 \\
2005 & -0.0051 & 0.0417 & 3.6833 & 0.0099 & 0.0066 & 0.0088 & 0.0105 \\
2006 & -0.0051 & 0.0417 & 3.6833 & 0.0099 & 0.0204 & 0.0058 & 0.0058 \\
2007 & -0.0051 & 0.0417 & 3.6833 & 0.0099 & 0.0148 & 0.0002 & -0.0006 \\
2008 & -0.0051 & 0.0417 & 3.6833 & 0.0099 & -0.0132 & -0.0070 & -0.0069 \\
2009 & -0.0051 & 0.0417 & 3.6833 & 0.0099 & -0.0522 & -0.0123 & -0.0109 \\
2010 & -0.0051 & 0.0417 & 3.6833 & 0.0099 & 0.0130 & -0.0135 & -0.0114 \\
\hline averages & & & & 0.0199 & 0.0203 & 0.0198 & 0.0197 \\
\hline
\end{tabular}

a 'Price' is the first summation in the numerator of Equation (3).

b 'Quantity' is the second summation in the numerator of Equation (3).

c 'Denominator' is the denominator of Equation (3).

d 'Constraint' is the BoP-constrained rate $\dot{Y}_{B P}$.

${ }^{\mathrm{e}}$ Evaluated using the Hodrick-Prescott filter with $\lambda=6.25$.

${ }^{\mathrm{f}}$ Evaluated using the asymmetric Christiano-Fitzgerald band-pass filter for $I(0)$ series, and period of oscillation between $p_{l}=2$ and $p_{u}=8$. 
Table 8. The tightening of the Bop constraint in the mid-Nineties

\begin{tabular}{|c|c|c|c|c|}
\hline & & \multicolumn{3}{|c|}{ sample averages } \\
\hline & & $1980-95$ & 1996-10 & $\Delta^{\mathrm{a}}$ \\
\hline \multirow[t]{7}{*}{ Real growth } & core & 0.021 & 0.016 & -0.005 \\
\hline & periphery & 0.024 & 0.028 & 0.005 \\
\hline & US & 0.036 & 0.025 & -0.011 \\
\hline & non€ & 0.029 & 0.021 & -0.009 \\
\hline & OPEC & 0.020 & 0.026 & 0.005 \\
\hline & BRIC & 0.068 & 0.072 & 0.003 \\
\hline & ROW & 0.026 & 0.025 & -0.002 \\
\hline \multirow[t]{7}{*}{ Relative prices } & core & 0.003 & 0.028 & 0.025 \\
\hline & periphery & 0.000 & 0.014 & 0.015 \\
\hline & US & 0.022 & 0.024 & 0.002 \\
\hline & non€ & 0.017 & 0.020 & 0.003 \\
\hline & OPEC & 0.101 & -0.039 & -0.140 \\
\hline & BRIC & 0.017 & -0.005 & -0.021 \\
\hline & ROW & 0.013 & 0.018 & 0.005 \\
\hline \multirow[t]{7}{*}{ Imports income elasticity } & core & 2.451 & 3.130 & 0.679 \\
\hline & periphery & 4.096 & 3.030 & -1.066 \\
\hline & US & 1.482 & 1.482 & 0.000 \\
\hline & non€ & 2.026 & 1.930 & -0.096 \\
\hline & OPEC & -0.175 & -0.175 & 0.000 \\
\hline & BRIC & 3.061 & 4.249 & 1.188 \\
\hline & ROW & 2.130 & 5.962 & 3.833 \\
\hline \multirow[t]{7}{*}{ Exports income elasticity } & core & 1.810 & 1.772 & -0.038 \\
\hline & periphery & 2.084 & 2.220 & 0.136 \\
\hline & US & 1.769 & 1.769 & 0.000 \\
\hline & non€ & 2.235 & 1.696 & -0.539 \\
\hline & OPEC & 0.331 & 0.331 & 0.000 \\
\hline & BRIC & 1.056 & 1.056 & 0.000 \\
\hline & ROW & 1.546 & 1.546 & 0.000 \\
\hline \multirow[t]{7}{*}{ Imports price elasticity } & core & -0.079 & 0.356 & 0.436 \\
\hline & periphery & 0.583 & 0.240 & -0.343 \\
\hline & US & 0.265 & 0.265 & 0.000 \\
\hline & non€ & -0.022 & -0.347 & -0.324 \\
\hline & OPEC & 0.165 & 0.165 & 0.000 \\
\hline & BRIC & 0.236 & -0.792 & -1.028 \\
\hline & ROW & -0.006 & 0.847 & 0.853 \\
\hline
\end{tabular}

${ }^{a}$ Variation of the sample averages between the two subsamples. 
Table 8. The tightening of the Bop constraint in the mid-Nineties (continued)

\begin{tabular}{|c|c|c|c|c|}
\hline & & \multicolumn{3}{|c|}{ sample averages } \\
\hline & & 1980-95 & 1996-10 & $\Delta^{\mathrm{a}}$ \\
\hline \multirow[t]{7}{*}{ Exports price elasticity } & core & -0.909 & -1.131 & -0.222 \\
\hline & periphery & -2.483 & -3.725 & -1.243 \\
\hline & US & -1.527 & -1.527 & 0.000 \\
\hline & non€ & -1.533 & -1.223 & 0.311 \\
\hline & OPEC & -0.709 & -0.709 & 0.000 \\
\hline & BRIC & -0.383 & -0.383 & 0.000 \\
\hline & ROW & -0.477 & -0.477 & 0.000 \\
\hline \multirow[t]{7}{*}{ Imports market shares } & core & 0.448 & 0.416 & -0.032 \\
\hline & periphery & 0.041 & 0.066 & 0.025 \\
\hline & US & 0.057 & 0.040 & -0.017 \\
\hline & non€ & 0.113 & 0.101 & -0.012 \\
\hline & OPEC & 0.112 & 0.066 & -0.046 \\
\hline & BRIC & 0.046 & 0.081 & 0.035 \\
\hline & ROW & 0.180 & 0.230 & 0.050 \\
\hline \multirow[t]{7}{*}{ Exports market shares } & core & 0.423 & 0.347 & -0.076 \\
\hline & periphery & 0.064 & 0.101 & 0.037 \\
\hline & US & 0.083 & 0.079 & -0.004 \\
\hline & non€ & 0.130 & 0.120 & -0.010 \\
\hline & OPEC & 0.079 & 0.042 & -0.037 \\
\hline & BRIC & 0.031 & 0.047 & 0.016 \\
\hline & ROW & 0.191 & 0.263 & 0.072 \\
\hline Numerator: volume effect & & 0.034 & 0.030 & \\
\hline Numerator: price effect & & 0.002 & -0.014 & \\
\hline Denominator & & 2.086 & 3.458 & \\
\hline Growth rate: actual & & $2.1 \%$ & $0.8 \%$ & $-1.3 \%$ \\
\hline Growth rate: constrained & & $1.7 \%$ & $0.5 \%$ & $-1.3 \%$ \\
\hline
\end{tabular}

${ }^{a}$ Variation of the sample averages between the two subsamples. 
Table 9. The linear decomposition of the Bop constraint tightening in the mid-Nineties

\begin{tabular}{lcccccccc|c}
\hline \multicolumn{1}{c}{ Core } & $\dot{Y}_{j}$ & $\dot{R}_{j}$ & $\mu_{j}$ & $v_{j}$ & $\varepsilon_{j}$ & $\eta_{j}$ & $\pi_{j}$ & \multicolumn{2}{l}{$\psi_{j}$} \\
\cline { 3 - 7 } Periphery & $12 \%$ & $7 \%$ & $-4 \%$ & $8 \%$ & $5 \%$ & $-1 \%$ & $16 \%$ & $0 \%$ & $44 \%$ \\
US & $-2 \%$ & $6 \%$ & $5 \%$ & $-6 \%$ & $-21 \%$ & $0 \%$ & $-2 \%$ & $0 \%$ & $-19 \%$ \\
other European & $5 \%$ & $1 \%$ & $0 \%$ & $0 \%$ & $0 \%$ & $0 \%$ & $0 \%$ & $0 \%$ & $5 \%$ \\
OPEC & $6 \%$ & $1 \%$ & $-1 \%$ & $1 \%$ & $0 \%$ & $2 \%$ & $-1 \%$ & $-2 \%$ & $6 \%$ \\
BRIC & $0 \%$ & $16 \%$ & $12 \%$ & $-7 \%$ & $0 \%$ & $0 \%$ & $0 \%$ & $0 \%$ & $21 \%$ \\
Row & $0 \%$ & $2 \%$ & $4 \%$ & $-3 \%$ & $0 \%$ & $0 \%$ & $3 \%$ & $-2 \%$ & $3 \%$ \\
& $2 \%$ & $-1 \%$ & $4 \%$ & $-8 \%$ & $0 \%$ & $0 \%$ & $37 \%$ & $6 \%$ & $39 \%$ \\
& $22 \%$ & $32 \%$ & $21 \%$ & $-15 \%$ & $-16 \%$ & $1 \%$ & $54 \%$ & $2 \%$ & $100 \%$ \\
\hline
\end{tabular}




\section{Figures}

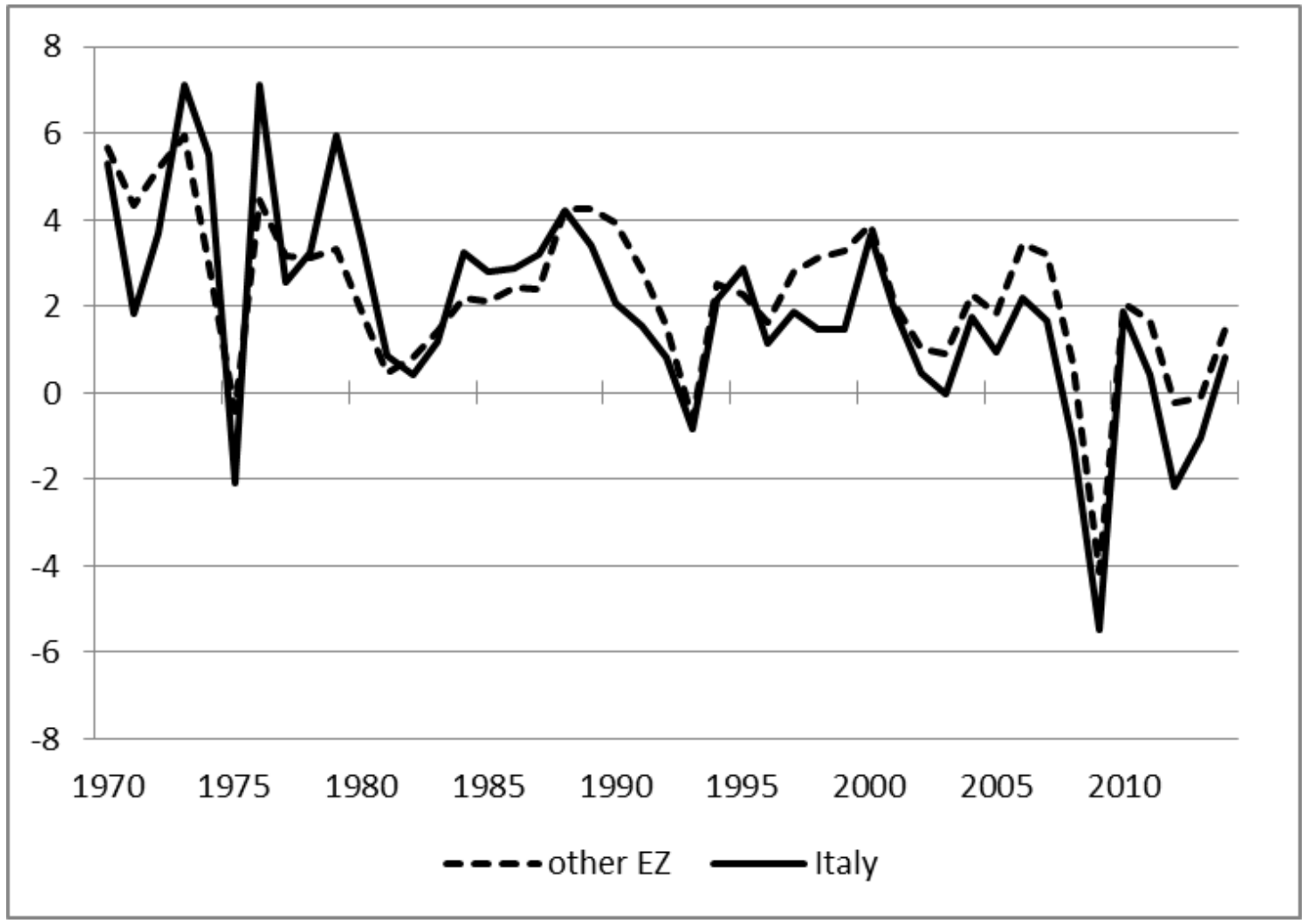

Figure 1. Real growth rates in Italy and in the other Eurozone countries

Source: AMECO (2013) 


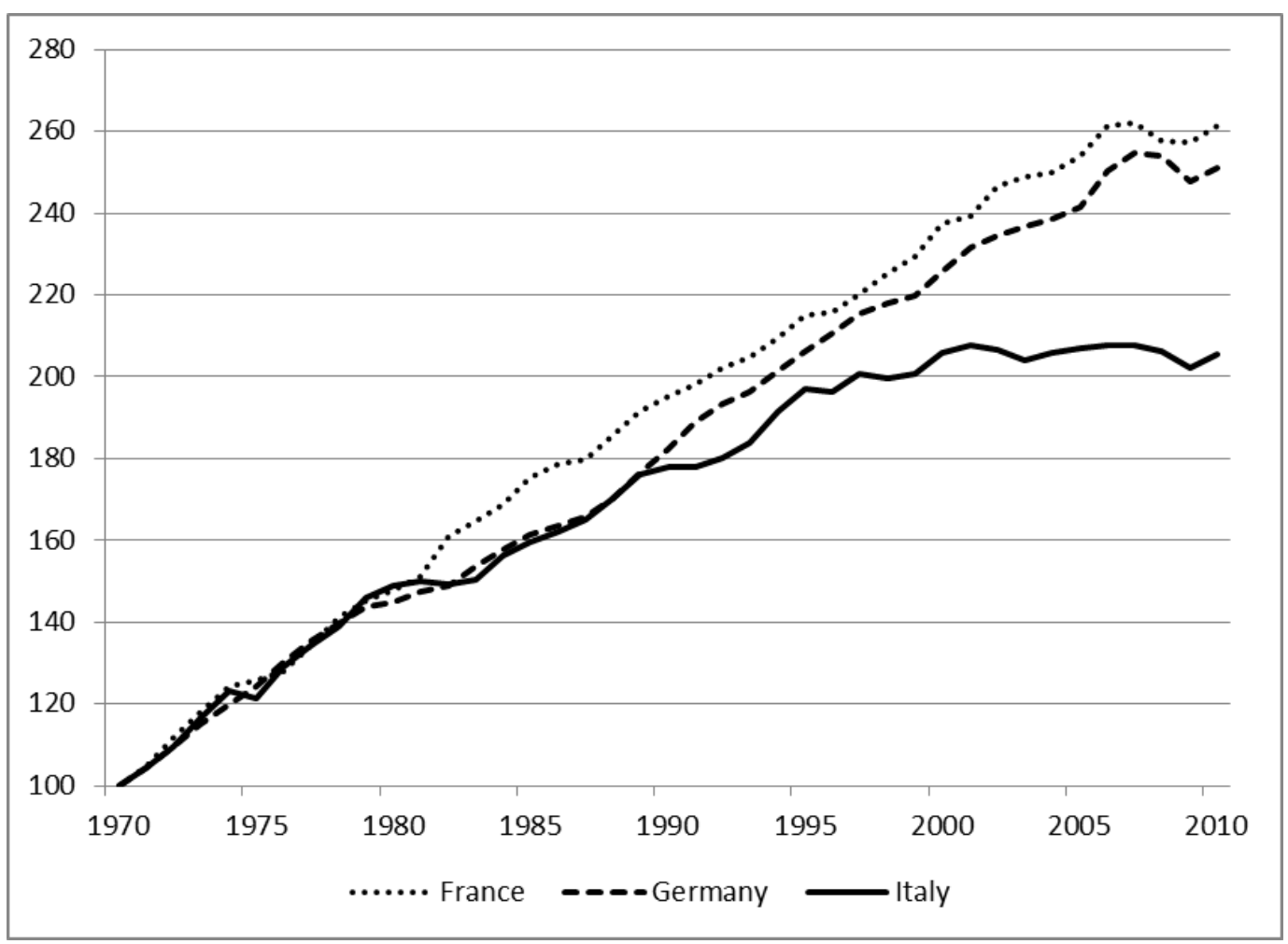

Figure 2. Labour productivity index, GDP per hour worked $(1970=100)$

Source: OECD (2013)

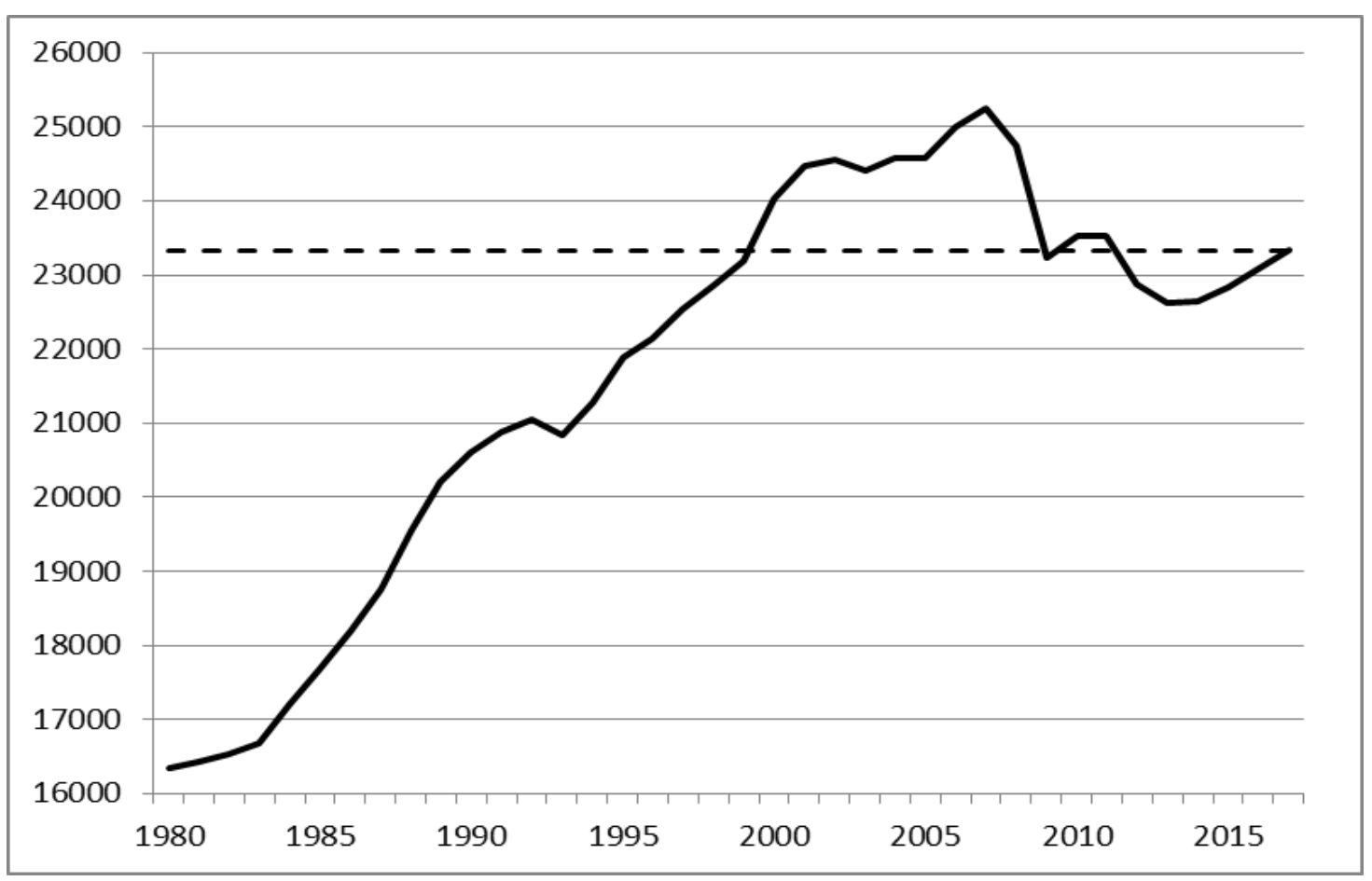

Figure 3. Real per capita GDP in Italy at 2005 prices

Source: IMF (2013) 


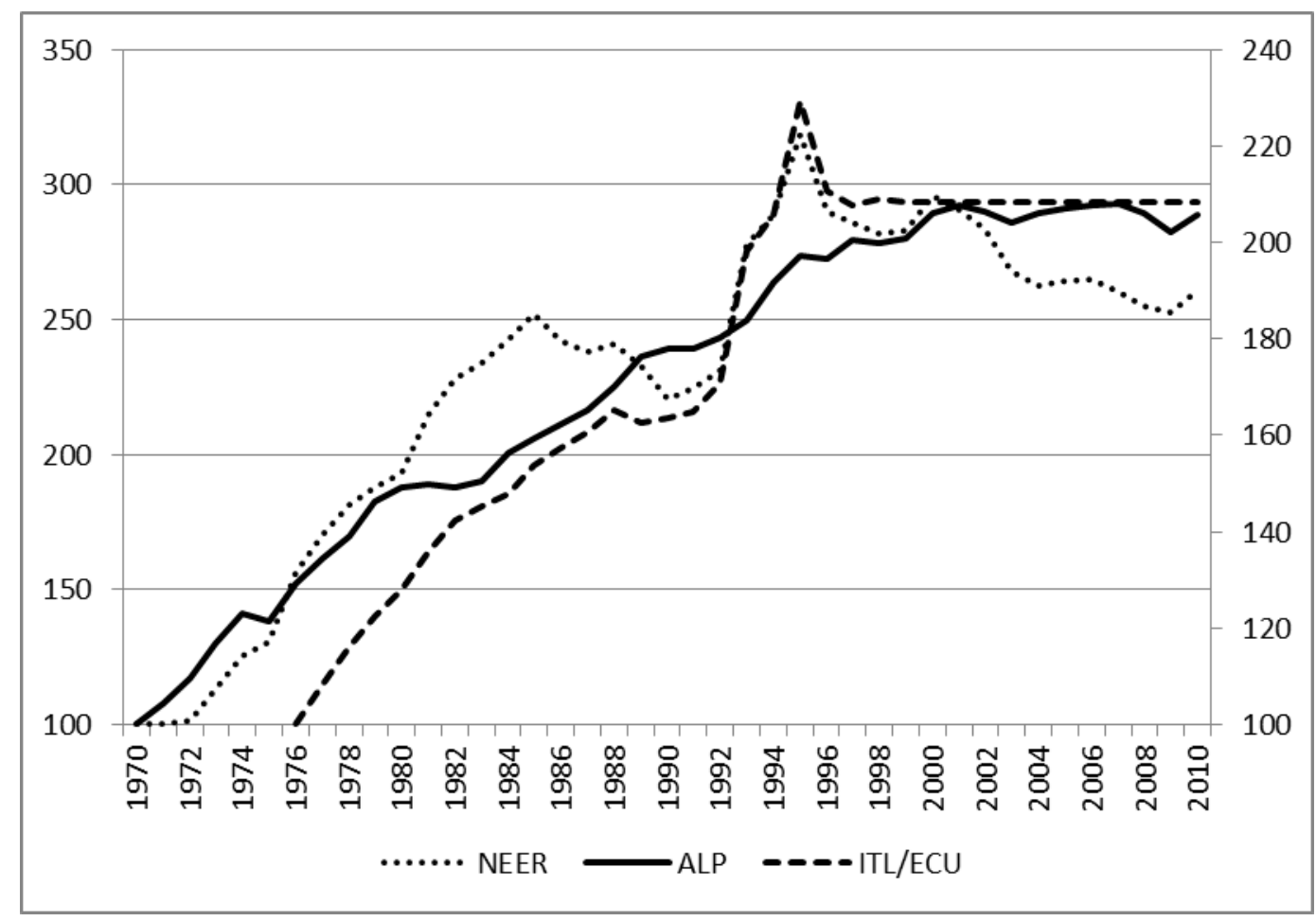

Figure 4. Average labour productivity index (ALP), measured as GDP per hour worked $(1970=$ 100, right hand scale); nominal effective exchange rate index (NEER, $1970=100$ ); ITL/ECU exchange rate index $(1976=100)$, left-hand scale

Source: ALP, OECD (2013), other variables IMF (2013) 


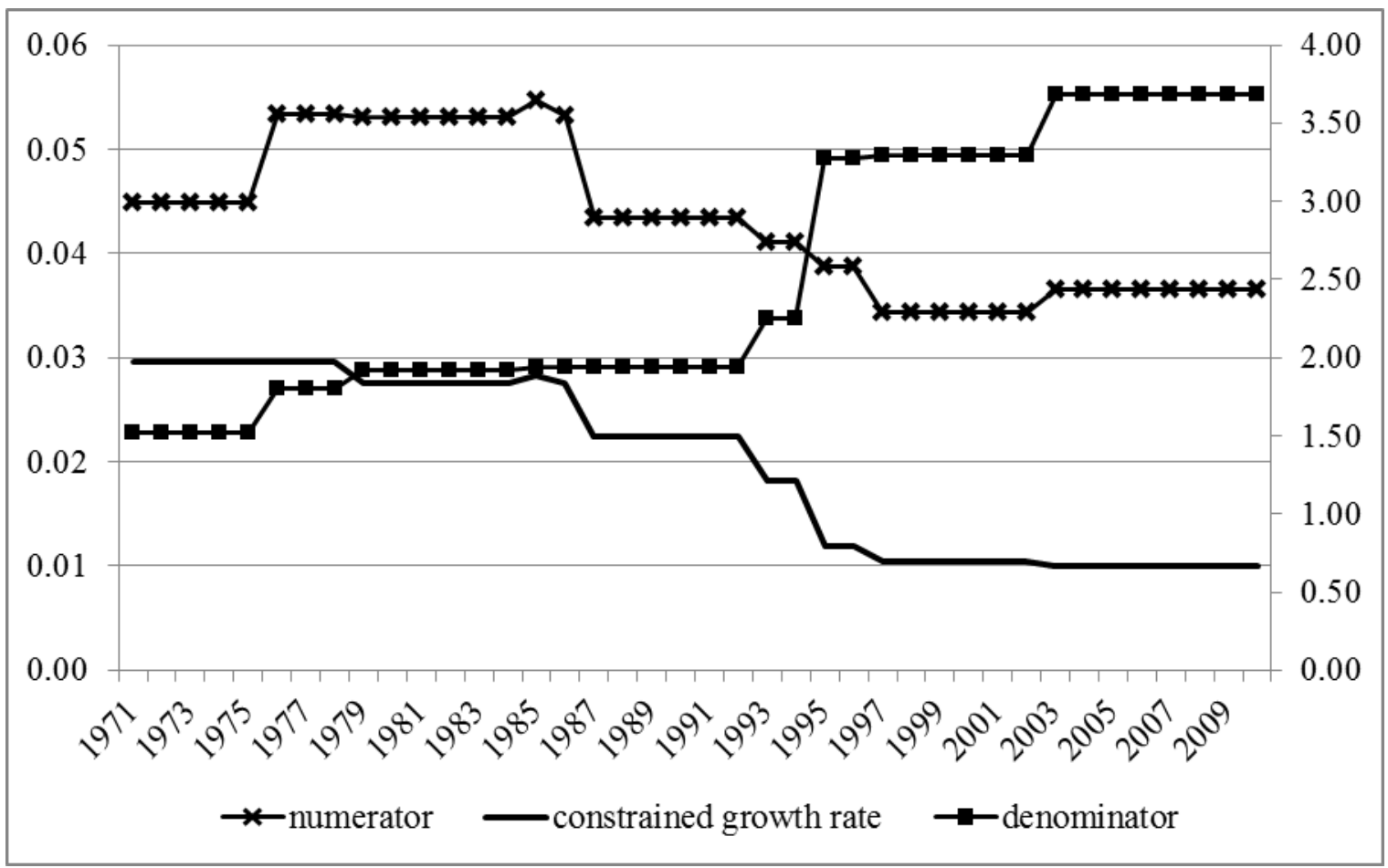

Figure 5. The time profile of the generalized Bop-constraint (3) and of its numerator and denominator (the latter plotted on the right-hand scale)

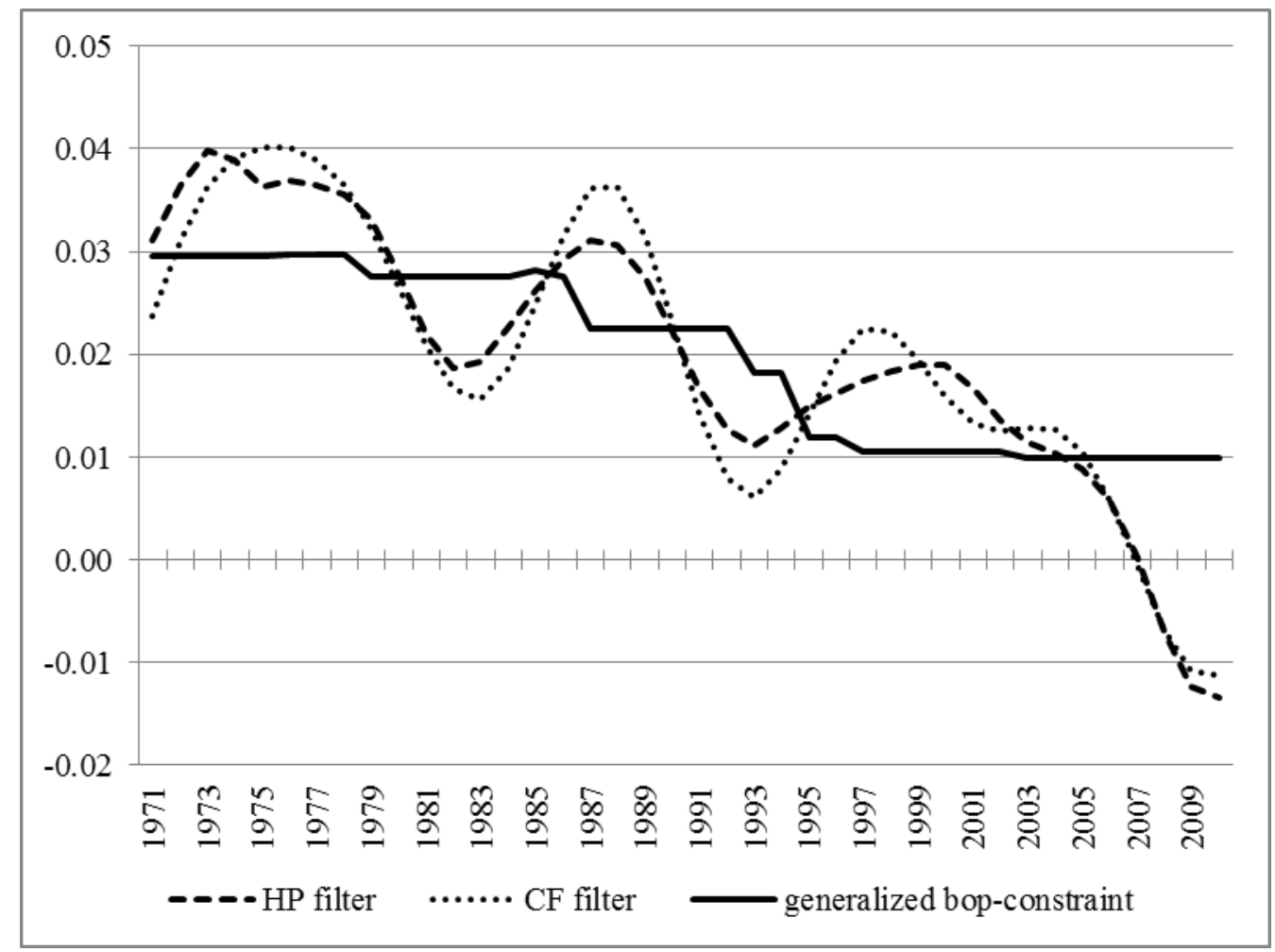

Figure 6. The generalized Bop constraint and long-run growth in Italy, 1971-2010 


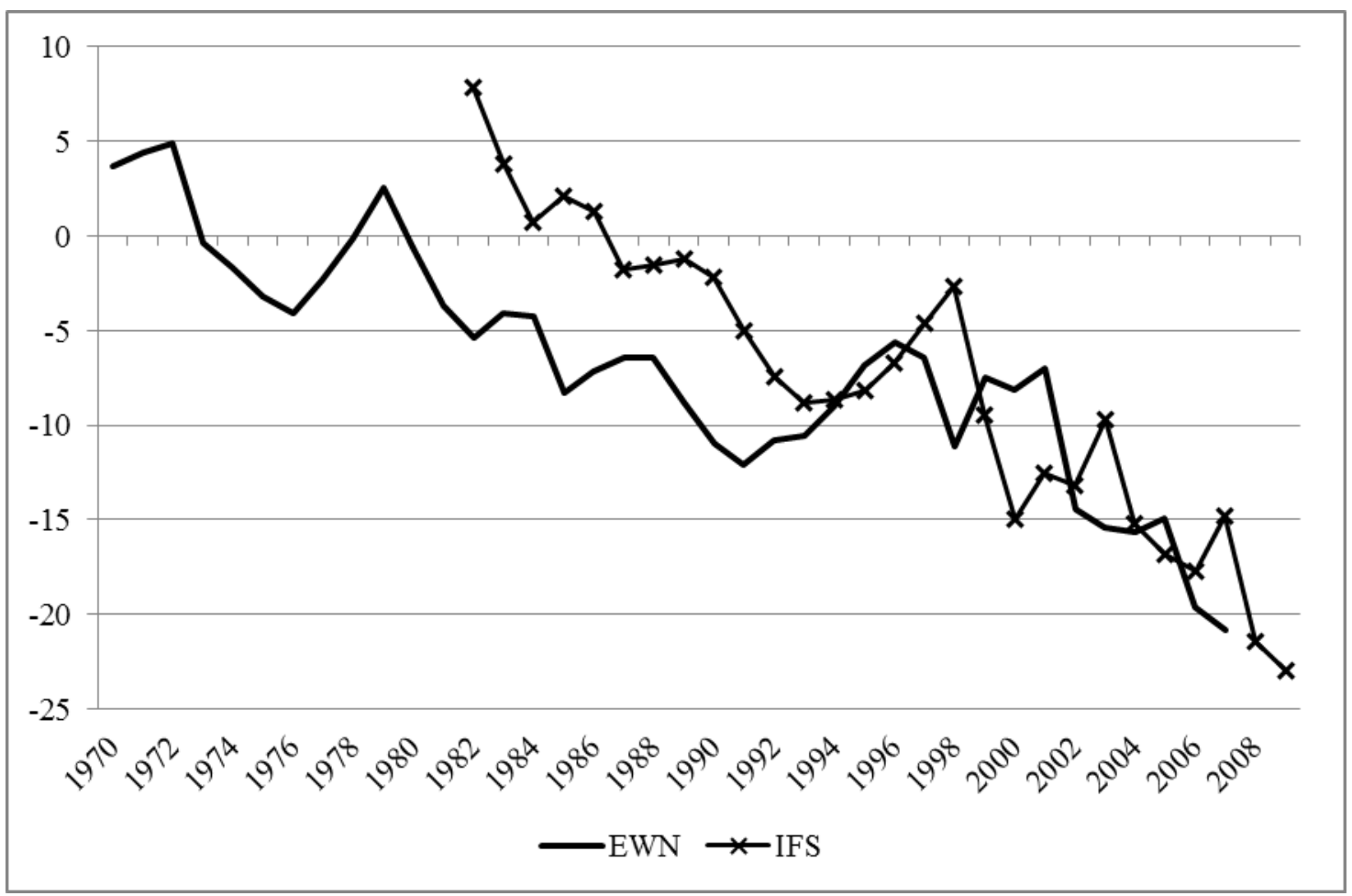

Figure 7. Two estimates of Italy's net foreign assets-to-GDP ratio

Source: EWN comes from the updated and extended version of the External Wealth of Nations Mark II database developed by Lane and Milesi-Ferretti (2007), IFS comes from the International Financial Statistics (IMF, 2010) 


\section{a/ working paper series}

Italian Association for the Study of Economic Asymmetries postal: via Filippo Marchetti 19, I-00199 Roma, Italy www.asimmetrie.org / email: info@asimmetrie.org

2016/05 Alberto Bagnai: ॥l decentramento in Italia, il percorso del regionalismo tra crisi economica e crisi della Costituzione

2016/04 Barra Caracciolo: Profili di illegittimità costituzionale della c.d. "Unione Bancaria" e del "bail-in" nel quadro della moneta unica

2016/03 Boltho, Carlin, Scaramozzino: Why East Germany Did Not Become A New Mezzogiorno

2016/02 Alberto Bagnai \& Christian Alexander Mongeau Ospina: Price Asymmetries in the European Gasoline Market

2016/01 Alessandro Cianci: Disoccupazione strutturale in Italia e regole europee di bilancio

2015/12 Roberto Frenkel: An Appraisal of Floating Exchange Rate Regimes in Latin America 2015/11 Paolo Becchi: È la fine dell'Europa?

2015/10 Sergio Cesaratto: L'organetto di Draghi: quattro lezioni critiche sulle misure non convenzionali della ECB sino al Quantitative Easing

2015/09 Stefan Kawalec: The Permanent Necessity to Undervalue the Euro Endangers Europe's Trade Relations

2015/08 Sergio Cesaratto: Alternative Interpretations of a Stateless Currency Crisis

2015/07 Vladimiro Giacché: Spiegare la crisi - Stagnazione secolare o caduta tendenziale del saggio del profitto?

2015/06 Giorgio Di Maio \& Paolo Landoni: Beyond the Gini index: Measuring Inequality With the Balance of Inequality Index

2015/05 Merike Kukk: How Did Household Indebtedness Hamper Consumption During the Recession? Evidence From Micro Data

2015/04 Gianluigi Nocella: Competitività e distribuzione funzionale nell'Eurozona

2015/03 Giovanni Battista Donato: The Cyprus Crisis and the Legal Protection of Foreign Investors

2015/02 Sergio Cesaratto: Fra Marx e List: sinistra, nazione e solidarietà internazionale

2015/01 Piotr Ciżkowicz \& Andrzej Rzońca \& Rafał Trzeciakowski: Membership in the Euro Area and Fiscal Sustainability - Analysis Through Panel Fiscal Reaction Functions

2014/07 Alberto Bagnai \& Christian Alexander Mongeau Ospina: Long- and Short-Run Price Asymmetries in the Italian Energy Market: the Case of Gasoline and Heating Gasoil

2014/06 Sergio Cesaratto: Balance of Payments or Monetary Sovereignty? In Search of the EMU's Original Sin - a Reply to Lavoie

2014/05 Alberto Bagnai \& Christian Alexander Mongeau Ospina: The a/simmetrie Annual Macroeconometric Model of the Italian economy: Structure and Properties

2014/04 Rodrigo M. Zeidan: Derivatives and Non-Financial Companies: Lessons From the Financial Crisis

2014/03 Carsten A. Holz: The Quality of China's GDP Statistics

2014/02 Josef C. Brada \& El-hadj Bah: Growing Income Inequality as a Challenge to 21st Century Capitalism

2014/01 Alberto Bagnai: Un External Compact per rilanciare l'Europa 
2013/02 Alberto Bagnai \& Arsène Rieber \& Anh-Dao Tran: Economic Growth and Balance of Payments Costraint in Vietnam

2013/01 Alberto Bagnai: Unhappy Families are all Alike: Minskyan Cycles, Kaldorian Growth, and the Eurozone Peripheral Crises

Our working papers are available at the following Internet addresses:

http://www.asimmetrie.org/category/working-papers/

https://ideas.repec.org/s/ais/wpaper.html 